Dear author,

Please note that changes made in the online proofing system will be added to the article before publication but are not reflected in this PDF.

We also ask that this file not be used for submitting corrections. 


\title{
An experimental investigation of a new perfect bond technology for composite slabs
}

\author{
Miquel Ferrer* ${ }^{*}$, Frederic Marimon, Miquel Casafont \\ Dept. of Strength of Materials and Structural Engineering, Universitat Politècnica de Catalunya BarcelonaTech (UPC), Spain
}

H I G H L I G H T S

- New full-connection bonding technology between steel sheet and concrete for composite slabs is presented and compared with common embossments technology.

- Full-connection between steel and concrete is achieved with the new system until yielding of both materials, regardless of the material type: ferritic stainless or common galvanized steel and normal or lightweight aggregate concrete.

- Longitudinal shear failure mode is practically extinguished.

- The ultimate loads with the new bonding technology are significantly greater than those with common embossments.

- The slabs including the new technology has shown significant ductility provided by material yielding.

\section{A R T I C L E I N F O}

\section{Article history:}

Received 7 September 2017

Received in revised form 15 January 2018

Accepted 19 January 2018

Available online $\mathrm{xxxx}$

\section{Keywords:}

Composite slabs

Longitudinal slip

Shear transfer

Full connection

Flooring system

\begin{abstract}
A B S T R A C T
Steel-concrete composite slabs generally fail due to the debonding with separation of sections caused by longitudinal shear forces, regardless of the shape of the sheeting profile or the design of the embossments. This article presents an innovative full-connection bonding technology, consisting of producing bands of many small crown-shaped cuttings in the profile webs as a replacement for the embossments. The new technology has been tested on three commercial sheeting profiles. The results of the investigation show that full connection is achieved with the new system, i.e., yielding of both materials occurs without any slip, in contrast to the partial connection of traditional embossments. The longitudinal shear strengths are 1.4-7 times higher. The specimens tested include the use of conventional galvanized steel and concrete, as well as ferritic stainless steel and lightweight aggregate concrete.
\end{abstract}

(c) 2018 Elsevier Ltd. All rights reserved.

\section{Introduction}

Steel-concrete slabs were first used in 1938 in the United States, although cold-formed steel sheeting was only used as permanent formwork [1]. During the 1960s, steel decks with embossments were introduced and widely developed, the sheeting becoming the actual tensile reinforcement of the slab. Extensive research into longitudinal shear response of composite slabs was pioneered by Porter and Ekberg [2]. Since then, countless shapes and forms of such embossments have been designed in order to obtain the best shear connection degree between steel and concrete. However, among the three typical failure modes in composite slabs: bending, vertical shear and longitudinal shear, the latter is widely the most restrictive. The classical four-point bending test is used to provoke

\footnotetext{
* Corresponding author.

E-mail address: miquel.ferrer@upc.edu (M. Ferrer).
}

longitudinal shear failure, detected by measuring the longitudinal relative slip at the ends of the slab (Fig. 1), and then to determine the empirical parameters used by two calculation methods: the m$\mathrm{k}$ and the Partial Shear Connection methods [3,4]. These two common methods are included in most standard codes [5-7]; however, they can lead to significantly different results $[8,9]$.

The function of embossments is similar to that of the corrugations on reinforcing bars for concrete; however, their shear resistance efficiencies are considerably different. In reinforced concrete, radial compression components are generated on the steel rebar by the wedge effect of corrugations, whose extremely high radial stiffness completely prevents any longitudinal slip until steel yielding. Consequently, full connection is achieved. By contrast, in composite slabs, once the steel-concrete chemical bond is broken, the wedge effect forces acting on the embossments cause local bending of the steel sheet due to its low stiffness, and the relative slipping between the steel profile and the concrete 

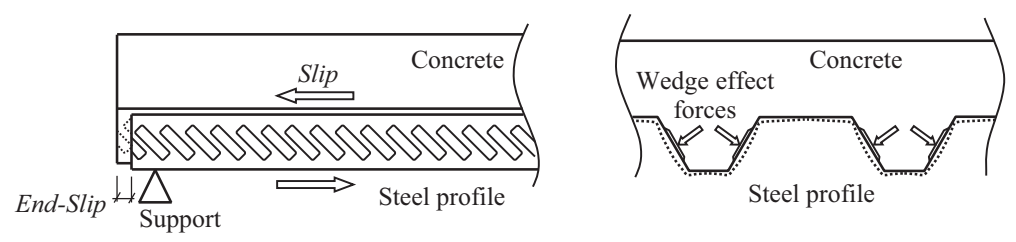

Transversal bending of the steel sheet due to slip wedge effect (dotted line)

Fig. 1. Slip behaviour scheme of composite slabs with common embossment.

develops easily (partial connection) (Fig. 1). It must be noted that, in favour of the shear failure ductility, the maximum resistance to longitudinal shear should be achieved after large slip has been developed. Therefore, relative slipping is an expected and desirable phenomenon when using embossments, in order to avoid brittleness in longitudinal shear failure

In open-rib profiles, when slip is high enough to free vertically the concrete from the sheeting, the load drops to null connection (Fig. 2). This fact often leads to an inefficient and premature failure of the slab, since the actual stresses of both materials when concrete is vertically freed are usually much lower than their ultimate capacities, as will be shown later in Section 6, where strain gauge measurements are presented.

Several researchers have studied the influence of different materials on the connection degree of embossed sheets, such as stainless steel [10] and high-performance or lightweight concretes $[11,12]$. The coating influence has also been investigated $[13,14]$. Pull-out and push-out test arrangements are commonly used to test and compare the efficiency of embossment designs [14,16], as well as bending load configurations [17,18]. Finite-element approaches to composite slab behaviour have been developed to better understand the slipping mechanics and to improve the current designs [15,18-22]. In these studies, the interaction between the embossments and the concrete is numerically treated as a contact problem considering adhesion and friction.

In summary, the structural efficiency of composite slabs greatly depends on their ability to transfer shear forces between steel profile and concrete. The main difficulty of steel deck designing lies in assuring the effective composite performance; i.e., to conceive systems which are highly resistant to relative slip and debonding. To date, the conventional embossment system has shown to be unable to overcome the longitudinal shear failure mode, despite all attempts to improve embossment efficiency.

This article presents an innovative full-connection bonding technology (Fig. 3a) [23], consisting of producing bands of many small crown-shaped cuttings in the profile webs, as a replacement for the common embossments' system (Fig. 3b). The performance of the two connection systems is compared by means of experi-

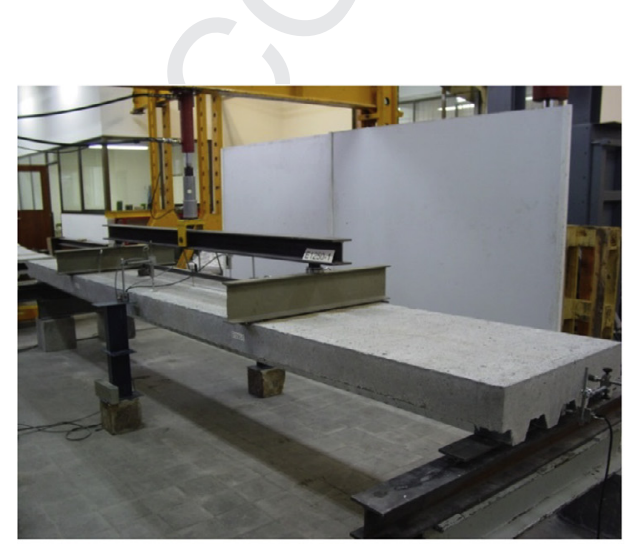

(a) mental tests which have been carried out following the classical four-point bending test procedure.

The experimental campaign includes slabs produced using three commercial open-rib trapezoidal profiles, from 60 to 80 $\mathrm{mm}$ in height, named A80, C60 and W60 in this article. A set of slabs is provided with the new system (detailed in Section 4), and a second set with conventional embossments. Three punching densities have been investigated: low (LD), medium (MD) and high density (HD); and two steel thicknesses.

In most cases, the sheeting profiles have been manufactured with conventional galvanized steel and concrete. Additionally, ferritic stainless steel sheets and lightweight aggregate concrete (expanded clay) have also been used to extend the evaluation of the new system to different materials. Only open-rib profiles have been used; the use of the new system in dovetail re-entrant profiles would probably lead to less competitive designs in terms of slab self-weight, materials saving or propping requirements.

\section{Theory of connection in composite slabs}

This section includes basic theory on the behaviour of composite slabs under four-point bending; in particular, the three stages for shear connection degree are outlined. The aim of the authors is to make the description of the investigation as clear as possible by outlining first some basic theoretical concepts that are relevant for understanding the behaviour of the proposed composite system and which will be used in the discussions presented in the subsequent sections of the article.

On the left side of the figures below (see Figs. 4-6), theoretical strain and stress distributions along the cross-section of the slab are shown. The right side shows qualitative force-deflection and force-slip behaviour curves of each connection stage.

The following nomenclature has been used:

$L$ is the span length, $L_{s}$ is the shear span length $\left(L_{s}=\mathrm{L} / 4\right), L_{x}$ is the distance from a general cross-section to the nearest support, $V$ is the reaction at the support, $N_{c}$ is the resultant of the compressive stresses in concrete $\left(\sigma_{c}\right)$ and $N_{s}$ is the resultant of stresses in the steel sheeting $\left(\sigma_{s}\right)$. The concrete tensile strength is neglected. The

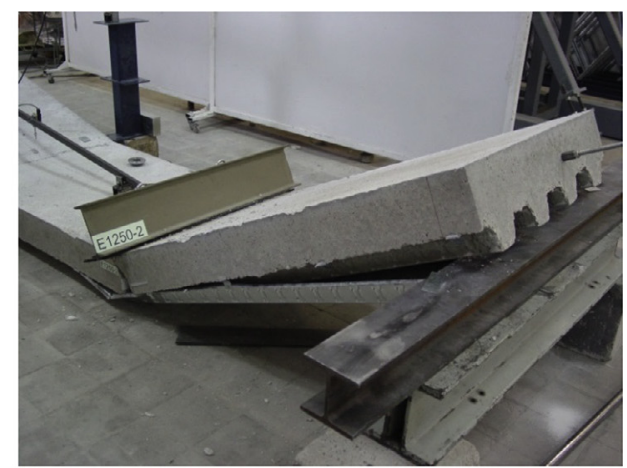

(b)

Fig. 2. a) Standard bending test set-up; b) Longitudinal slip failure and vertical detachment. 


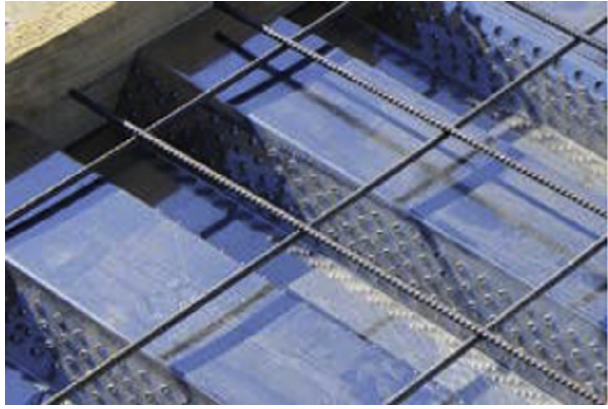

(a)

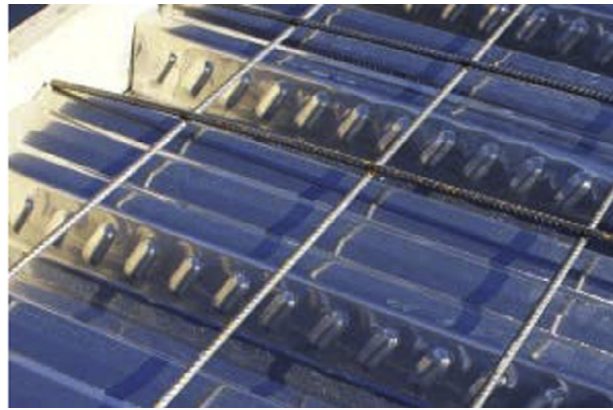

(b)

Fig. 3. a) Innovative UPC bonding technology; b) Conventional profiled sheeting with embossments.
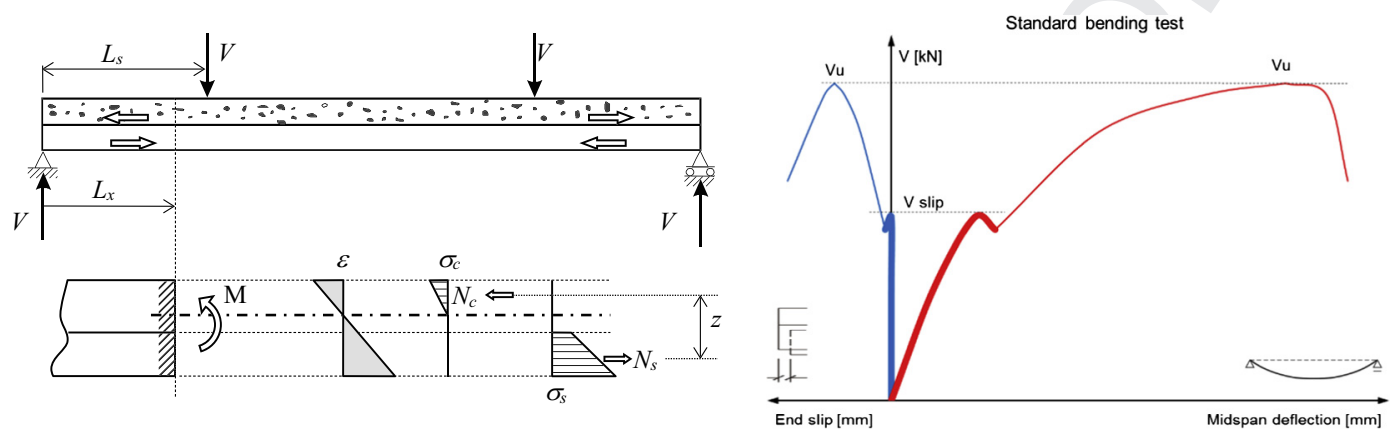

Fig. 4. Example of full connection or perfect bond case.
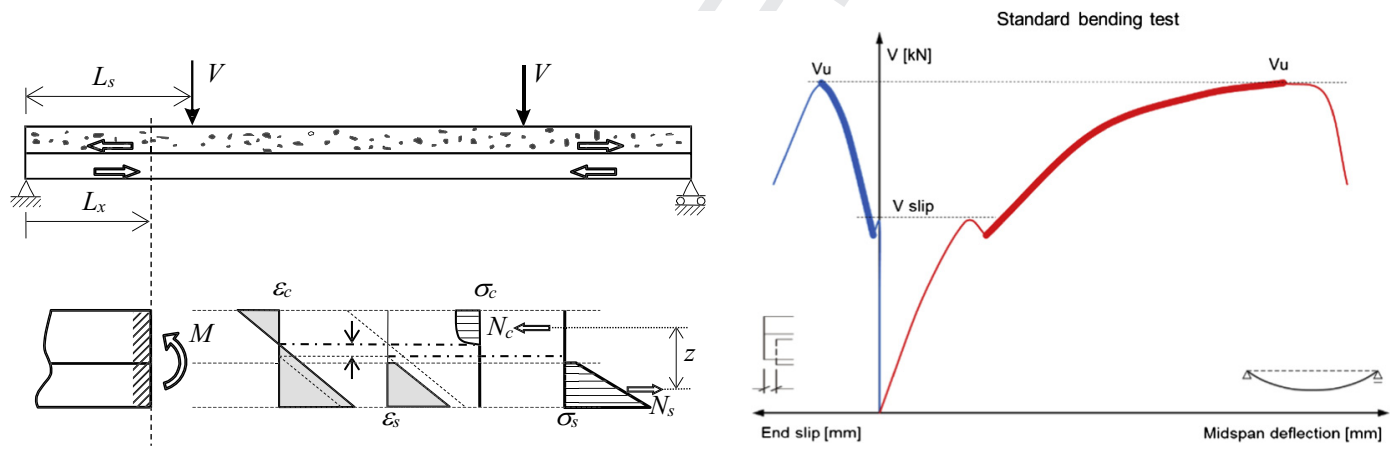

Fig. 5. Example of partial connection case.
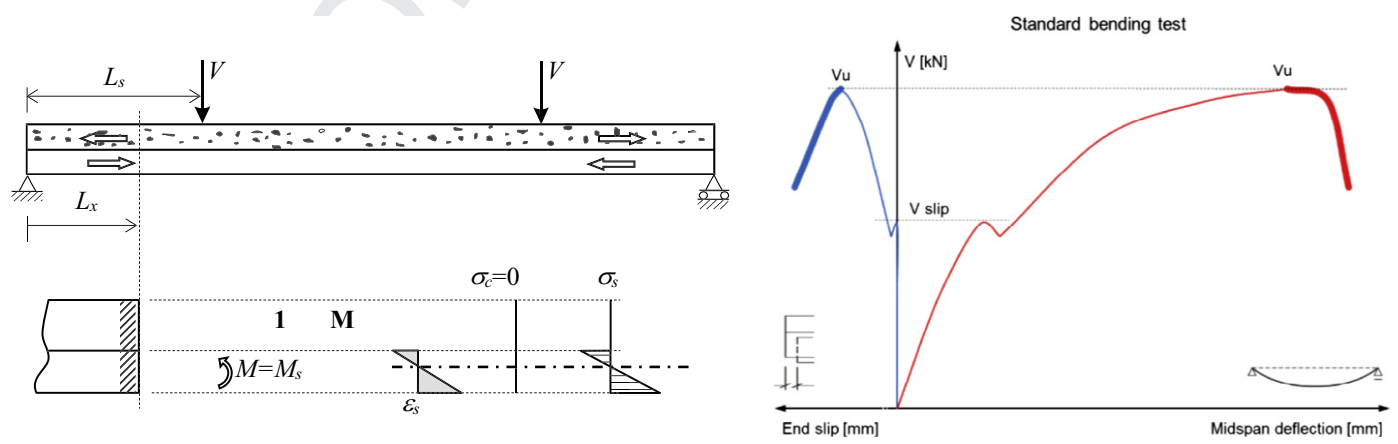

Fig. 6. Null connection case with no tensile rebars.

position of the neutral axis can be determined, since $N_{c}=N_{s}$ due to equilibrium condition, and the bending moment is then: $M=N_{c} \cdot z$ or $N_{s} \cdot z$, where $z$ is the lever arm, distance between $N_{c}$ and $N_{s}$.

\subsection{Full connection}

Fig. 4 outlines the full-connection scheme, without any relative slip between steel profile and concrete. Shear forces are fully trans- 
ferred and the strain continuity and linearity throughout the crosssection can be accepted. Both materials work together as a single structural element. The concrete under tension is assumed to be cracked. Steel and compressed concrete are assumed to be below their yielding limits.

Generally, full connection is always kept in the first loading stage of any composite slab design. Nevertheless, as load increases, most sheeting designs with conventional embossments can no longer keep transferring the required shear forces and first slip occurs between the two materials. The partial connection stage, described next, is thus developed.

\subsection{Partial connection}

The longitudinal shear forces between materials cannot increase beyond a given bonding strength and, therefore, the interface connection breaks all along the shear span and slip starts growing. Therefore, the strain continuity throughout the slab depth is no longer acceptable and two neutral axes can be outlined within the composite cross-section; one for the steel profile, which can be inside or outside the sheeting profile, and another for the concrete (Fig. 5). Linearity of strains for each material and equal curvatures are still assumed.

From the first slip, and right through the partial connection stage until the slab failure, the aim of the embossments is to hinder the slipping process in such a way that the load increases as long as possible in favour of ductility as slip grows.

\subsection{Null connection}

Finally, if shear forces are not transferred at all, the slab should be considered as the sum of two independent bending elements working without any connection. If no longitudinal rebars are provided in the concrete ribs, as is the case of the standard $\mathrm{m}-\mathrm{k}$ bending test (see Section 5), the sheeting is actually the only resisting element, given that the concrete element cannot resist its tensile bending stresses by itself (Fig. 6) and it cracks completely.

The collapse of most bending tests can be considered at the initiation of the null (or low) connection stage, especially in the case of open-rib profiles, where transfer of shear forces drops because of the complete vertical detachment of steel profile and concrete.

\section{The new bonding technology}

The new bonding system developed and patented by the authors on behalf of the UPC [23], from now on named UPCSystem, consists of producing bands of many small crownshaped cuttings by punching the steel sheet before profiling (Fig. 7). Every punched band is faced to its opposed symmetric band on the adjacent web of the rib. No punches are made in the flanges to prevent significant reduction of steel sheet resistance and stiffness, which plays an important role in the slab construction stage. After concrete pouring and hardening, the projections of such cuttings remain embedded inside the concrete, so that the shear forces between the steel and the concrete are fully transferred when the composite slab is loaded. As will be shown in Section 6 , full connection is achieved up to materials yielding.

The effectiveness of this invention lies, on the one hand, on the small size of the crowns, many in number and uniformly distributed, so that the shear forces are not excessively concentrated in specific points. Local breakage of the concrete, as well as excessive deformation of the projections themselves is thus prevented. Thus, shear transmission occurs in a similar way to that of the only-friction and rusted-surface mechanisms tested by Porter and Ekberg [13], in which longitudinal shear forces are transmitted by friction only and distributed over the whole contact surface between the steel profile and the concrete. In [13], it can be observed that the friction mechanism is especially effective in the non-galvanized rusted-surface case.

On the other hand, its effectiveness also lies in complete punching (Fig. 7a), whereby the punch completely traverses the steel sheet until the cutting is as open as possible (Fig. 7b). Thus, such a cutting greatly reduces the detachment movement of the two materials, since the wedge effect between them is also greatly reduced, unlike the embossments case. Actually, an active resistance to detachment is developed by the crown-shaped cuttings since they are inserted inside the concrete.

This invention is highly effective in transferring shear forces between steel profile and concrete due to the coexistence of the following advantages compared to other systems: a widely distributed transmission of shear forces; the absence of elements with a sharp geometry which would easily break concrete; no resistance dependency on the direction of shear forces; no tearing failure is produced on the sheet and forces separating steel profile and concrete are minimal.

The practical contribution of this invention is the achievement of full connection until materials yielding and, in practice, the suppression of the longitudinal shear failure mode. As will be seen in Section 6, the failure loads obtained in bending tests are close to those corresponding to the ultimate theoretical full-connection bending moment of the composite cross-section, which are calculated as below.

Fig. 8 outlines the scheme of the ultimate full-connection stage, where $F$ is the load cell force (or cylinder force). Note that the effect of the weights of the slab $\left(W_{\text {slab }}\right)$ and the spreader beams $\left(W_{\text {spreader }}\right)$ must be added to effect $F$ when the resistance of the slab is determined.

According to the stress distribution and parameters described in Fig. 8, corresponding to the case with the neutral axis located above the sheeting, the ultimate full-connection bending moment of the composite cross-section can be theoretically calculated as follows:

$$
M_{u f u l l}=N_{s} \cdot z=A_{p e} f_{y} \cdot\left(d_{p}-x / 2\right)=A_{p e} f_{y} \cdot\left(d_{p}-A_{p e} f_{y} /\left(2 b f_{c}\right)\right)
$$

where, $A_{p e}$ Effective area of the sheeting corresponding to the slab width $b$ (the punched/embossed area is not taken into account).

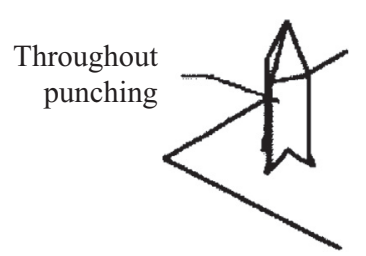

(a)

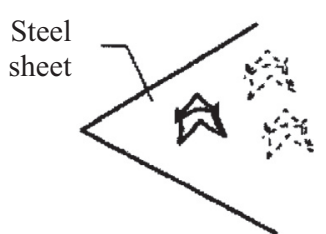

(b)

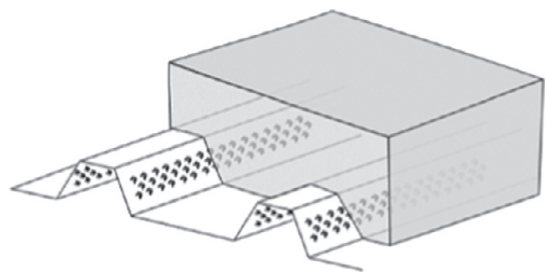

(c)

Fig. 7. a) Throughout square punching; b) Resulting cutting on steel sheet; c) Use on composite slab sheeting. 


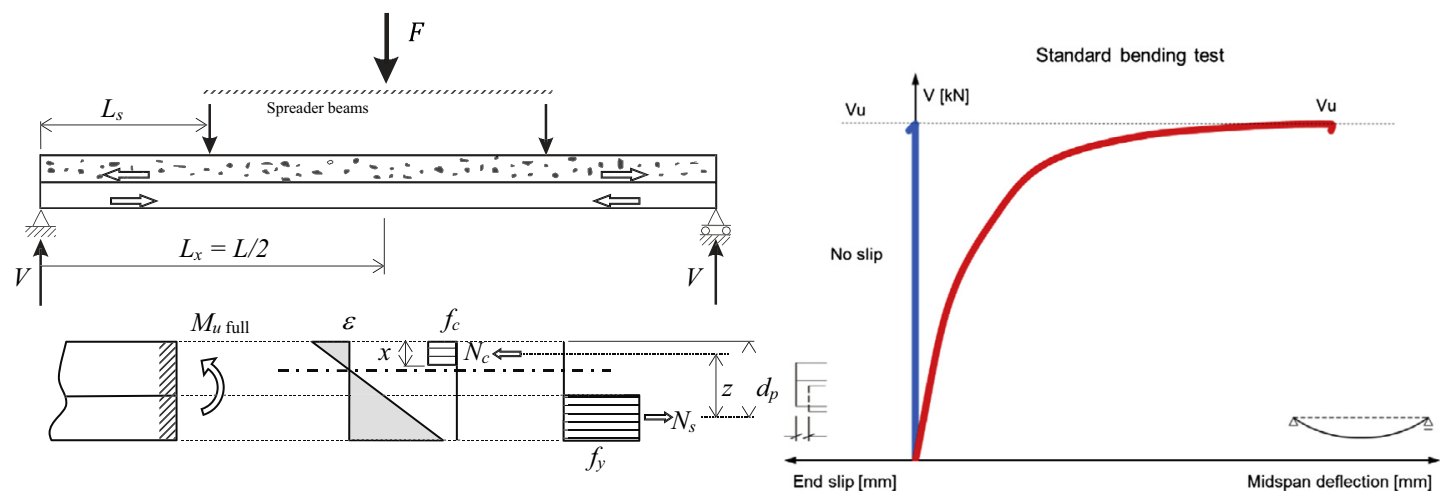

Fig. 8. Ultimate limit state under full connection. Case with the neutral axis located above the sheeting.

$d_{p}$ Distance between the upper fibre and the centroid of the sheeting. $x$ Height of the compressed concrete block. $f_{y}$ Mean yield stress of the steel (from real experimental values) $f_{u}$ Mean ultimate strength of the steel (from real experimental values), as an alternative to $f_{y}$ (see Section 6). $f_{c}$ Concrete strength under compression (from real experimental values).

In order to evaluate the achievement of full-connection until the failure of the slab and, so, the efficiency of the new bonding system, the theoretical ultimate full-connection resistance $\left(F_{u}\right.$ full $)$ will be compared to the tested experimental values $\left(F_{u \text { test }}\right)$ in Section 0 below. This comparison is made in terms of the load cell force $F$, instead of the bending moment $M$.

The relation between the load cell force $F$ and the bending moment $M$ at the midspan can be easily obtained by taking into account the contribution of the total weight of slab and spreader beams, as follows: $M=0.5\left(F+W_{\text {spreader }}\right) \cdot L_{s}+W_{\text {slab }} \cdot L / 8$, and, given that $L=4 \cdot L_{s}$, then $F=2 M / L_{s}-W_{\text {slab }}-W_{\text {spreader }}$. Combining with the previous $\boldsymbol{M}_{\boldsymbol{u f u l l}}$ expression, the theoretical ultimate fullconnection load cell force can be determined as: $F_{\text {ufull }}=2 A_{p e} f_{y} \cdot\left(d_{p}-A_{p e} f_{y} /\left(2 b f_{c}\right)\right) / L_{s}-W_{\text {slab }}-W_{\text {spreader }}$, and compared to experimental value $F_{\text {utest }}$ (see Section 6 ).

\subsection{Punching process and densities}

The punching process was applied to flat steel sheets by means of a punching device especially designed for this purpose (Fig. 9). After punching, the flat sheets were profiled. The cuttings are 4-tips crown-shaped, obtained by means of $4 \mathrm{~mm}$ square punches. The matrix arrangement is 4 (transversal) $\times 6$ (longitudinal) punches, whose axes are separated $10 \mathrm{~mm}$ in both directions.

This configuration is named Full high-density (Fig. 9a, Fig. 10a and Fig. 12,c), HD from now on, and its band linear density is 400 crowns per metre.

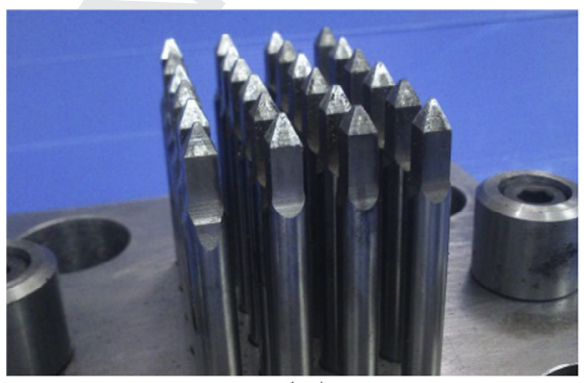

(a)

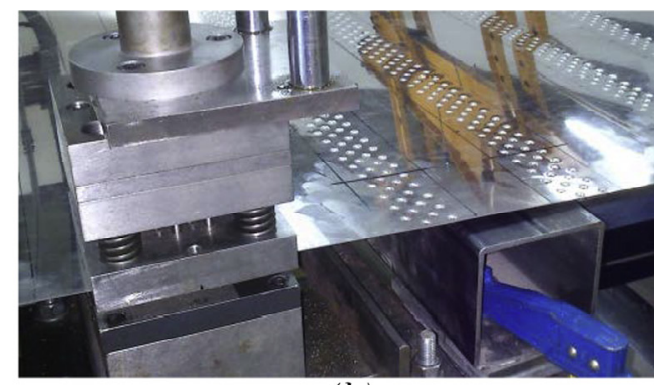

(b)
A Staggered Low-density configuration (Fig. 9b, Fig. 10b and Fig. 11c), named LD configuration, has also been used. It is generated by removing half of the punches from the punching press matrix, leading to a band linear density of 200 crowns per metre.

These two preliminary configurations, HD and LD, were initially designed for A80 and C60 profiles without any previous experience or previous results and based on intuition only, in order to have a reasonable crown size and densities. Afterwards, a third intermediate punches density was designed to be used in a new commercial profile, named W60 in this paper. This intermediate density, named Staggered Medium-density configuration (Fig. 13c), MD from now on, was implemented by the manufacturer of W60 profile. It is obtained by following the same 4 rows $4 \mathrm{~mm}$ punches press procedure, but reducing the longitudinal distance between punches axes so that the band linear density is 330 crowns per metre. This intermediate density, MD, has been conceived to improve the probable weakness of the HD design due to web-crippling in the construction stage, when the sheeting has to support the fresh concrete weight by itself. Specific research is being carried out into the behaviour of the sheeting in the construction stage depending on punching density.

In all cases, the punched areas in the sheet were distributed over the most suitable locations, i.e., the bands that will become the webs of the ribs after profiling.

The outer surface must be coated after punching with a sealing layer (plastic film, paint, impregnation, etc.) to prevent dripping when the concrete is poured. This is the case of the tested prototypes, where a band of adhesive tape was bonded manually before pouring the concrete (Fig. 10b). In practice, the commercial steel profile is delivered with an ultra-thin plastic film already bonded to the outer surface by the manufacturer.

\subsection{Sheeting geometries and materials}

Three commercial designs, described below, have been used to compare the new UPC-System with the conventional embossment technology.

4.2.1. A80 profile

The conventional embossed A80 profile (Fig. 11) -designed in 2002 by the authors of this article for a local manufacturer- was made of $0.8 \mathrm{~mm}$ thick galvanized steel sheet. Serial-made non-embossed specimens with the new bonding technology were supplied by the manufacturer (Fig. 11c). Slabs were made with conventional concrete.

Fig. 9. a) Square punches matrix; b) Punching a flat steel sheet (LD). 


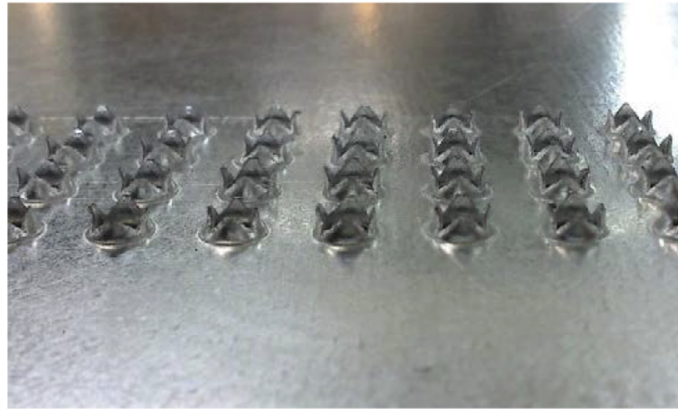

(a)

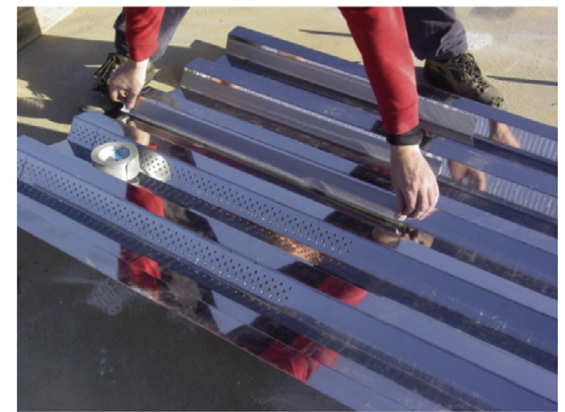

(b)

Fig. 10. a) Crown-shaped cuttings on flat sheet (HD); b) Manually bonding an adhesive tape (C60LD).

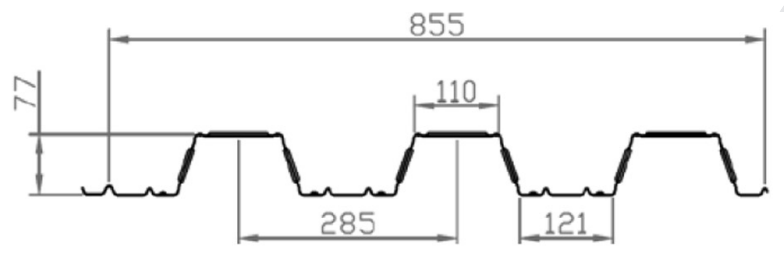

(a) $[\mathrm{mm}]$

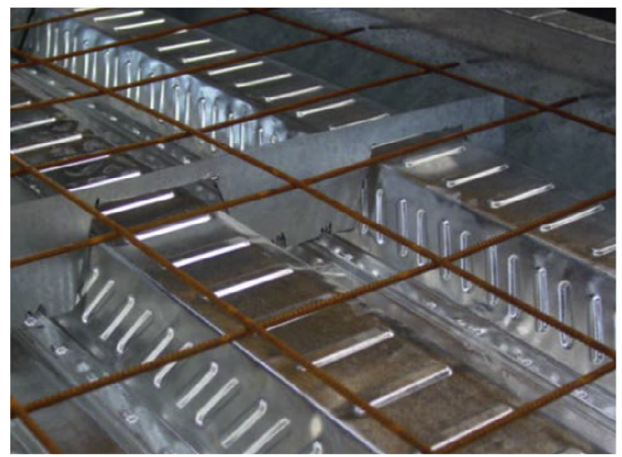

(b)

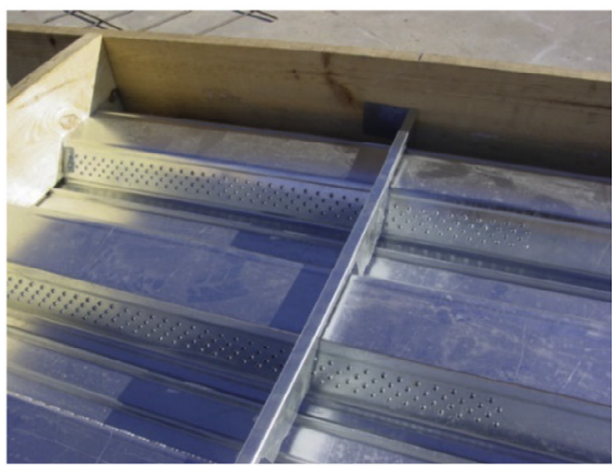

(c)

Fig. 11. A80: a) Embossed drawing; b) Detail of embossed specimen; c) Detail of LD punched specimen.

\subsection{3. $W 60$}

The W60 profile is manufactured by a local company, who supplied the conventional embossed W60 sheeting, and the serial-made non-embossed specimens with the MD UPC-System (Fig. 13). All specimens were made with conventional galvanized steel sheeting.

In this case, it was decided that the steel sheet should be $1.2 \mathrm{~mm}$ in nominal thickness in order to test the maximum potential bending capability in fullconnection. On the other hand, it must be noted that the higher the sheet thickness, the more difficult the embossing process and, probably, the lower the efficiency of embossments. In fact, as will be shown in Section 6, the W60 specimens have shown the greatest strength differences between embossed and punched specimens.

Additionally, 6 punched specimens were made with $0.75 \mathrm{~mm}$ nominal sheet thickness and lower span length: three of them with conventional concrete, and the other three with lightweight aggregate concrete (expanded clay).
Table 1 summarizes the properties of the tested specimens. Those specimens marked with an asterisk*, were instrumented with strain gauges bonded on both materials, steel and concrete.

\section{Bending test set-up}

The tests have been carried out following the above-mentioned standard four-point bending test procedure, commonly used to provoke longitudinal shear failure in the slabs [5-7]. Notice that relative slip between the steel sheeting and the concrete can occur at any of the two end supports independently. Fig. 14 shows the test set-up.

In the cases where 3 specimens of the same type have been tested, the cycle loading procedure has been applied to specimens \#2 and \#3, as stated in standards [5-7], based on the resistance of specimen \#1 tested under monotonic loading. The cyclic loading of specimens \#2 and \#3 consists of 5000 cycles between $20 \%$ and $60 \%$ of the strength of specimen \#1; afterwards, these specimens are loaded until failure.

Linear displacement sensors measure the deflection at midspan $\left(\mathrm{d}_{3}\right.$ and $\left.\mathrm{d}_{4}\right)$. Furthermore, there are two other displacement sensors fixed to the concrete at each end of the slab for measuring any relative movement with respect to the sheeting $\left(\mathrm{d}_{1}\right.$ and $\left.\mathrm{d}_{2}\right)$. 


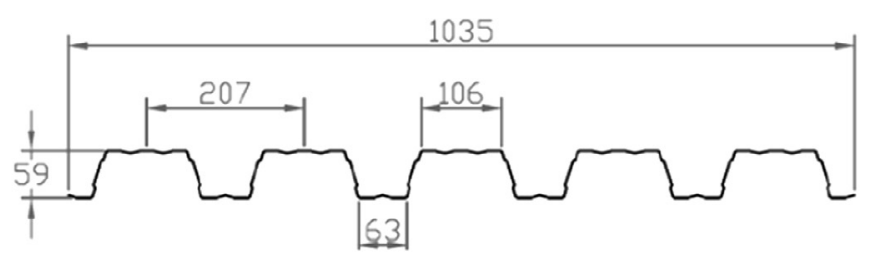

(a) $[\mathrm{mm}]$

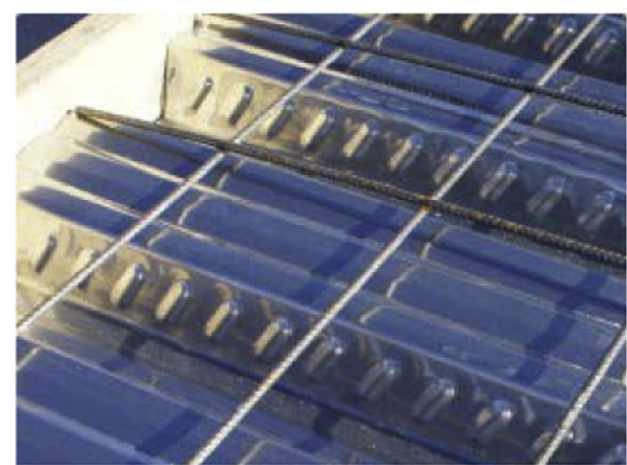

(b)

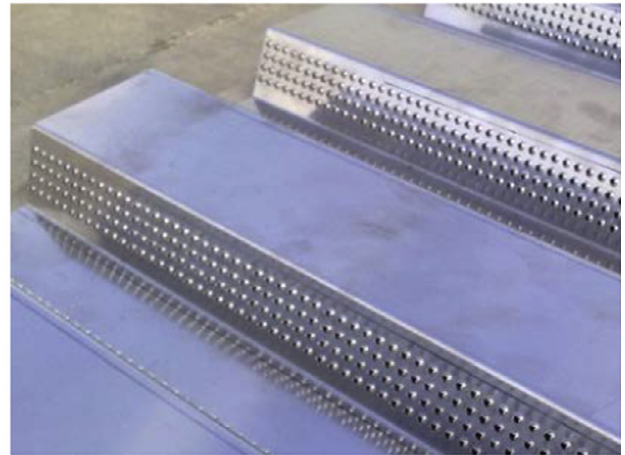

(c)

Fig. 12. C60 Sheeting: a) Embossed profile drawing; b) Embossed (E); c) Full high-density punched (HD).

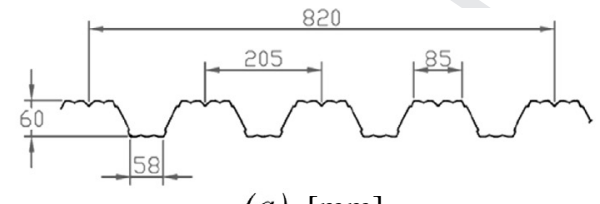

(a) $[\mathrm{mm}]$

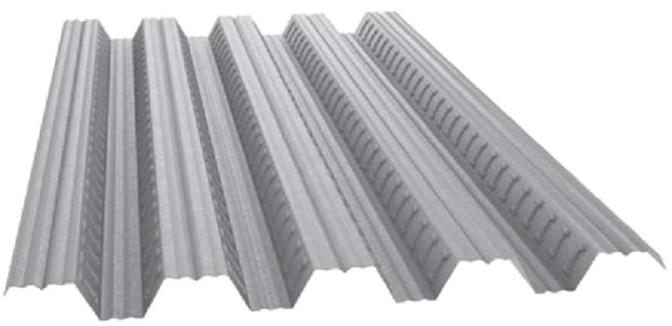

(b)

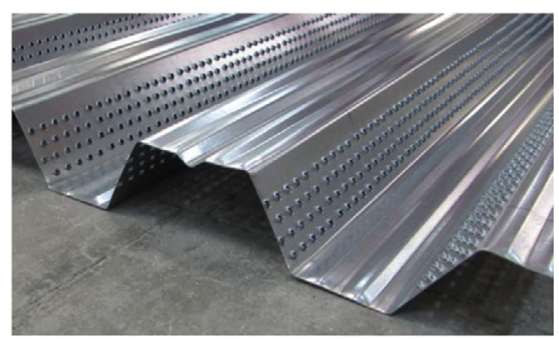

(c)

Fig. 13. W60 Sheeting: a) Embossed profile drawing; b) Embossed (E); c) Medium-density punched (MD).

In A80 and C60 specimens, an additional curvature measuring system, which includes sensor $d_{5}$, was incorporated to get the central curvature of the slab (see Fig. 15a and b). However, the curvature measurements are not presented in this article.

In order to check if full connection was kept until yielding of both materials, strain gauges were bonded longitudinally on steel and concrete surfaces, as shown in Fig. 16a (only in those specimens marked with * in Table 1). Gauges g1 and g4 were placed on the upper flange of the steel profile, while g2 and g3 on the lower flange; all of them were placed approximately at the centre of the planar longitudinal bands (see Fig. 16a), on the outer face of the sheeting (Fig. 16b left). Gauge g5 was bonded on the upper concrete surface (Fig. 16b right). All of the gauges, g1 to g5, were placed at the midspan cross-section.

\section{Results and discussion}

Table 2 below summarizes the experimental results of all specimens, where:
$\boldsymbol{F}_{\mathbf{0 . 1}} \mathbf{~ m m}$ slip: load cell force at $0.1 \mathrm{~mm}$ slip.

$\boldsymbol{F}_{\mathbf{0 . 5}} \mathbf{~ m m}$ slip: load cell force at $0.5 \mathrm{~mm}$ slip.

$\boldsymbol{F}_{\boldsymbol{u}}$ test: ultimate load cell force.

$\boldsymbol{F}_{\mathbf{L} / \mathbf{5 0}}$ : load cell force corresponding to L/50 midspan deflection (only if $\mathrm{L} / 50$ is reached).

sMidspan: midspan deflection at $F_{u}$ test.

Slip: longitudinal end-slip at $F_{u}$ test.

Table 3 below summarizes the comparison between the experimental ultimate load cell force $F_{u t e s t}$ and the theoretical fullconnection load cell force $F_{\text {ufull }}$, described in Section 3, where ratio $=F_{u \text { test }} / F_{\text {ufull }}$. The uniform load $q_{u \text { test }}$-equivalent to $F_{u \text { test }}-$ has been added as a reference.

The bar diagram in Fig. 17 summarizes the comparison between experimental mean strengths and the theoretical full-connection strength - using the ultimate stresses $f_{u^{-}}$for each specimen (dashed lines). The punched specimens (green) can be compared to embossed specimens (grey) for every sheeting design. 
Table 1

Summary of specimens and properties.

\begin{tabular}{|c|c|c|c|c|c|c|c|c|c|c|c|}
\hline \multirow[t]{2}{*}{ Specimen code } & \multicolumn{2}{|l|}{ Materials } & \multirow{2}{*}{$\begin{array}{l}\text { Actual steel } \\
\text { thickness } \\
t[\mathrm{~mm}]\end{array}$} & \multirow[t]{2}{*}{$A_{p e}\left[\mathrm{~mm}^{2}\right]$} & \multirow{2}{*}{$\begin{array}{l}\text { Total length } \\
L_{t}[\mathrm{~mm}]\end{array}$} & \multirow{2}{*}{$\begin{array}{l}\text { Span length } \\
L[\mathrm{~mm}]\end{array}$} & \multirow{2}{*}{$\begin{array}{l}\text { Height } \\
h_{t}[\mathrm{~mm}]\end{array}$} & \multirow{2}{*}{$\begin{array}{l}\text { Width } \\
b[\mathrm{~mm}]\end{array}$} & \multirow{2}{*}{$\begin{array}{l}d_{p} \\
{[\mathrm{~mm}]}\end{array}$} & \multirow{2}{*}{$\begin{array}{l}\text { Weight } \\
{[\mathrm{kN}]}\end{array}$} & \multirow[t]{2}{*}{ Bonding system } \\
\hline & Steel & Concrete & & & & & & & & & \\
\hline A80-E-n ${ }^{\circ} 1,2,3$ & Galvanized & Normal & 0.76 & 656 & 2600 & 2400 & 180 & 855 & 143 & 7.5 & Embossed \\
\hline A80-HD* & Galvanized & Normal & 0.76 & 820 & 2600 & 2400 & 180 & 855 & 143 & 7.5 & HD punched \\
\hline A80-LD & Galvanized & Normal & 0.76 & 820 & 2600 & 2400 & 180 & 855 & 143 & 7.5 & LD punched \\
\hline C60-E-CSteel & Galvanized & Normal & 0.76 & 865 & 2600 & 2500 & 100 & 1013 & 68 & 3.9 & Embossed \\
\hline C60-E-Inox-n ${ }^{\circ} 1^{*}, 2,3$ & Stainless & Normal & 0.8 & 910 & 2600 & 2500 & 100 & 1013 & 68 & 3.9 & Embossed \\
\hline C60-HD & Stainless & Normal & 0.8 & 1083 & 2600 & 2500 & 100 & 1013 & 68 & 3.9 & HD punched \\
\hline C60-LD & Stainless & Normal & 0.8 & 1083 & 2600 & 2500 & 100 & 1013 & 68 & 3.9 & LD punched \\
\hline W60-E-1.2 & Galvanized & Normal & 1.16 & 752 & 3300 & 3200 & 180 & 820 & 148 & 10.6 & Embossed \\
\hline W60-MD-1.2-n ${ }^{\circ} 1^{*}, 2,3$ & Galvanized & Normal & 1.16 & 1141 & 3300 & 3200 & 180 & 820 & 148 & 10.6 & MD punched \\
\hline W60-MD-n* ${ }^{*}, 2,3$ & Galvanized & Normal & 0.71 & 699 & 2500 & 2400 & 180 & 820 & 148 & 7.0 & MD punched \\
\hline W60-MD-LC-n ${ }^{\circ} 1^{*}, 2,3$ & Galvanized & Lightweight & 0.71 & 699 & 2500 & 2400 & 180 & 820 & 148 & 7.0 & MD punched \\
\hline
\end{tabular}

* with strain gauges (Shaded files: Embossed specimens).
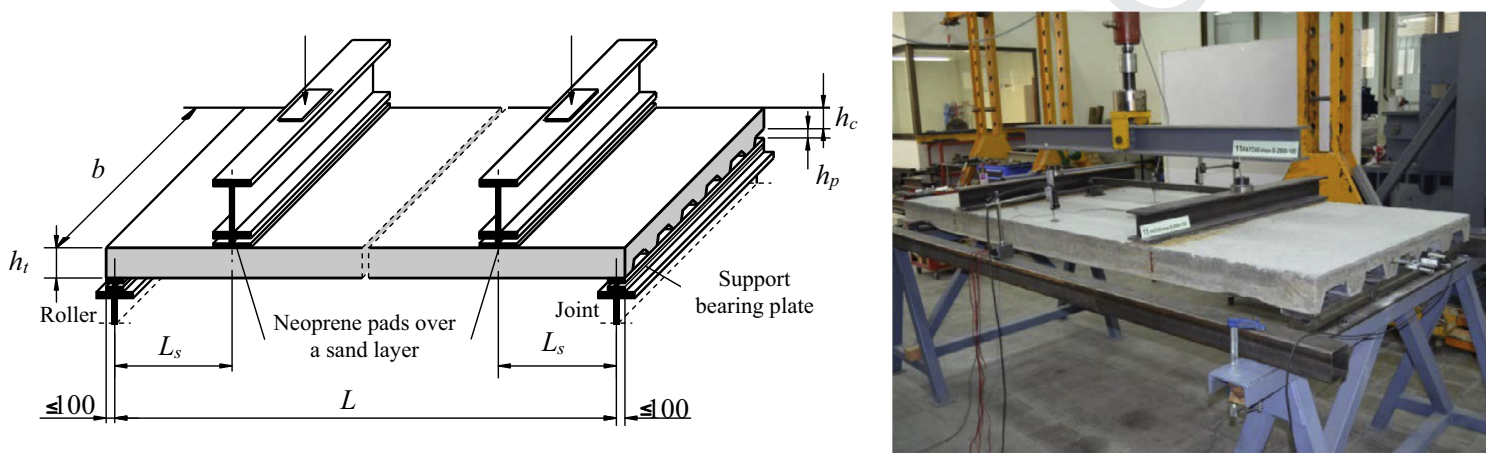

Fig. 14. Test set-up.

(Plan view of the slab)

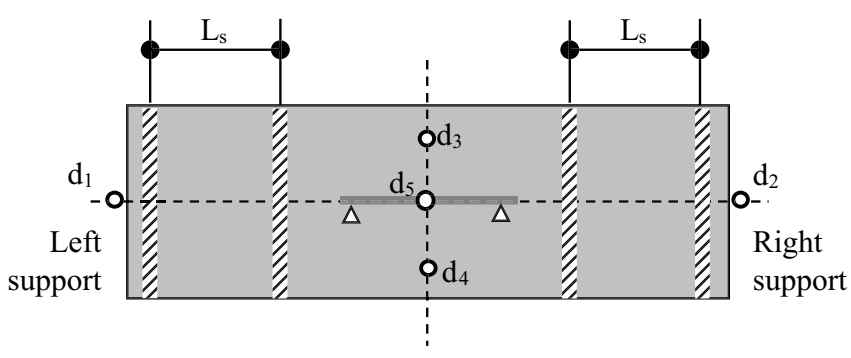

(a)

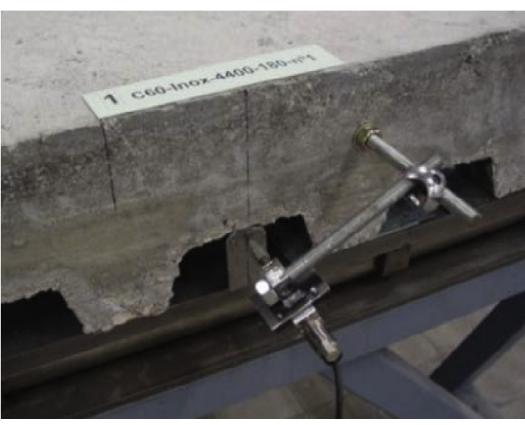

(b)

Fig. 15. a) Displacement transducers positions; b) Detail of end-slip sensor d2.

Table 3 and Fig. 17 clearly show that the strength values for all of the UPC-System specimens (green bars) are:

- Significantly greater than the equivalent embossed specimens for each profile design (grey bars).

- Greater than the theoretical full-connection strength using $f_{y}$ (ratio > 1.00 in Table 3 ).

- Close to the theoretical full-connection strength using $f_{u}$ (dashed lines).

For a better qualitative understanding of the results, some force-deflection and force-strain diagrams are shown below, together with the approximate strain distribution diagram along the slab cross-section depth at $0.9 F_{\text {utest }}(10 \%$ lower than ultimate loads in order to prevent any wrong value due to debonded gauges). In these diagrams, the behaviour pointed out in Section 2, concerning the strain discontinuities corresponding to partial connection (embossed specimens) and the strain linearity corresponding to full connection (punched specimens), is qualitatively verified.

These results are discussed below in detail and separately for each type of sheeting.

\subsection{A80 specimens}

The embossed specimens showed the common partial connection slipping process described in Section 2.2 , since $0,7 \mathrm{~mm}$ to $2,1 \mathrm{~mm}$ slip values were registered, as shown in Table 2 . In contrast, no slip was measured in the UPC-System specimens until failure, so full connection is kept. Failure loads were 1.4 and 1.7 times 


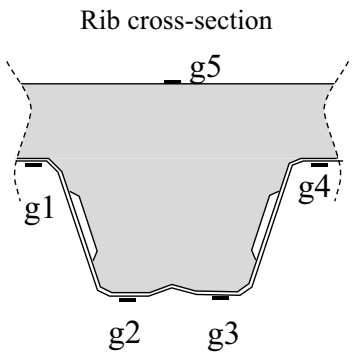

(a)
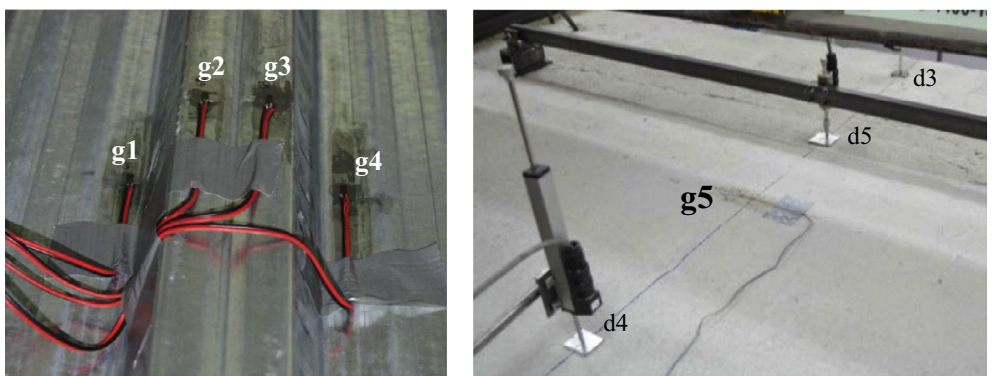

(b)

Fig. 16. a) Strain gauges scheme over the rib cross-section; b) Detail of strain gauges on steel sheeting (left) and concrete (right).

Table 2

Results summary.

\begin{tabular}{|c|c|c|c|c|c|c|c|c|}
\hline \multirow[b]{2}{*}{ Specimen code } & \multirow[b]{2}{*}{ Bonding system } & \multirow[b]{2}{*}{ Test type } & \multicolumn{4}{|l|}{$F$ Load cell forces } & \multicolumn{2}{|c|}{ Displacements at $F_{u \text { test }}$} \\
\hline & & & $F_{0.1 \mathrm{~mm} \text { slip }}[\mathrm{kN}]$ & $F_{0.5 \mathrm{~mm} \text { slip }}[\mathrm{kN}]$ & $F_{u \text { test }}[\mathrm{kN}]$ & $F_{\mathrm{L} / 50}[\mathrm{kN}]$ & $\delta_{\text {Midspan }}[\mathrm{mm}]$ & Slip [mm] \\
\hline A80-E-n ${ }^{\circ} 1$ & Embossed & Static & 60.1 & 68.6 & 75.9 & - & 13.7 & 2.1 \\
\hline A80-E-n`2 & Embossed & Cyclic + Static & 65.6 & 77.7 & 85.0 & - & 10.2 & 0.9 \\
\hline A80-E-n ${ }^{\circ} 3$ & Embossed & Cyclic + Static & 77.7 & 83.8 & 84.2 & - & 11.2 & 0.7 \\
\hline A80-HD & Punched & Static & - & - & 141.5 & - & 33.6 & no slip \\
\hline A80-LD & Punched & Static & - & - & 118.1 & - & 13.1 & no slip \\
\hline C60-E-CSteel & Embossed & Static & 23.5 & 20.0 & 34.1 & 34.1 & 36.1 & 75.2 \\
\hline C60-E-Inox-n ${ }^{\circ}$ & Embossed & Static & 3.6 & 9.8 & 34.5 & 34.5 & 35.0 & 52.6 \\
\hline C60-E-Inox-n ${ }^{\circ} 2$ & Embossed & Cyclic + static & 3.5 & 9.9 & 36.7 & 36.7 & 39.5 & 70.7 \\
\hline C60-E-Inox-n³ & Embossed & cyclic + static & 4.4 & 7.9 & 34.9 & 34.9 & 36.2 & 66.8 \\
\hline C60-HD & Punched & Static & - & - & 83.1 & 69.3 & $>90.0$ & no slip \\
\hline C60-LD & Punched & Static & - & - & 90.7 & 75.0 & $>120.0$ & no slip \\
\hline W60-E-1.2 & Embossed & Static & 17.6 & 17.6 & 25 & 17.6 & $>134.0$ & 15.6 \\
\hline W60-MD-1.2-n 1 & Punched & Static & - & - & 179.1 & 173.3 & 83.9 & no slip \\
\hline W60-MD-1.2-n`2 & Punched & Cyclic + static & - & - & 176.8 & - & 68.1 & no slip \\
\hline W60-MD-1.2-n³ & Punched & Cyclic + static & - & - & 175.7 & 174.3 & 81.4 & no slip \\
\hline W60-MD-n¹ & Punched & Static & - & - & 155.0 & 152.9 & 54.5 & no slip \\
\hline W60-MD-n² & Punched & Cyclic + static & - & - & 152.5 & 152.4 & 48.3 & no slip \\
\hline W60-MD-n³ & Punched & Cyclic + static & - & - & 156.0 & - & 44.7 & no slip \\
\hline W60-MD-LC-n`1 & Punched & Static & - & - & 146.4 & - & 30.1 & no slip \\
\hline W60-MD-LC-n² & punched & cyclic + static & - & - & 125.9 & - & 17.3 & no slip \\
\hline W60-MD-LC-n³ & Punched & Cyclic + static & - & - & 141.7 & - & 35.4 & no slip \\
\hline
\end{tabular}

Table 3

Experimental strength compared to theoretical full-connection strength.

\begin{tabular}{|c|c|c|c|c|c|c|c|c|c|c|}
\hline \multirow[t]{3}{*}{ Specimen code } & \multirow[t]{3}{*}{ Bonding system } & \multirow{3}{*}{$\begin{array}{l}\text { Steel } \\
\text { Yield stress } f_{y} \\
{\left[\mathrm{~N} / \mathrm{mm}^{2}\right]}\end{array}$} & \multirow{3}{*}{$\begin{array}{l}\text { Ultimate stress } f_{u} \\
\left.\mathrm{~N} / \mathrm{mm}^{2}\right]\end{array}$} & \multirow{3}{*}{$\begin{array}{l}\text { Concrete } \\
\text { Compression strength } f_{c} \\
{\left[\mathrm{~N} / \mathrm{mm}^{2}\right]}\end{array}$} & \multicolumn{2}{|c|}{ Experimental } & \multicolumn{4}{|c|}{ Theoretical $\boldsymbol{F}_{\boldsymbol{u} \text { full }}$} \\
\hline & & & & & \multirow{2}{*}{$\begin{array}{l}\boldsymbol{F}_{\boldsymbol{u} \text { test }} \\
{[\mathrm{kN}]}\end{array}$} & \multirow{2}{*}{$\begin{array}{l}\boldsymbol{q}_{\boldsymbol{u} \text { test }} \\
{\left[\mathrm{kN} / \mathrm{m}^{2}\right]}\end{array}$} & \multicolumn{2}{|c|}{ With $f_{y}$} & \multicolumn{2}{|c|}{ With $f_{u}$} \\
\hline & & & & & & & {$[\mathrm{kN}]$} & Ratio & {$[\mathrm{kN}]$} & Ratio \\
\hline A80-E-n`1 & Embossed & 313 & 397 & 30.7 & 75.9 & 37.0 & 89.2 & 0.85 & 113.8 & 0.67 \\
\hline A80-E-n ${ }^{\circ} 2$ & Embossed & 313 & 397 & 30.7 & 85.0 & 41.4 & 89.2 & 0.95 & 113.8 & 0.75 \\
\hline A80-E-n ${ }^{\circ} 3$ & Embossed & 313 & 397 & 30.7 & 84.2 & 41.1 & 89.2 & 0.94 & 113.8 & 0.74 \\
\hline A80-HD & Punched & 313 & 397 & 39.0 & 141.5 & 69.0 & 113.0 & 1.25 & 143.9 & 0.98 \\
\hline A80-LD & Punched & 313 & 397 & 39.0 & 118.1 & 57.6 & 113.0 & 1.04 & 143.9 & 0.82 \\
\hline C60-E & Embossed & 350 & 420 & 39.0 & 34.2 & 13.5 & 58.8 & 0.58 & 70.3 & 0.49 \\
\hline C60-E-Inox-n ${ }^{\circ}$ & Embossed & 320 & 480 & 39.0 & 34.5 & 13.6 & 56.5 & 0.61 & 83.9 & 0.41 \\
\hline C60-E-Inox-n² & Embossed & 320 & 480 & 39.0 & 36.7 & 14.5 & 56.5 & 0.65 & 83.9 & 0.44 \\
\hline C60-E-Inox-n³ & Embossed & 320 & 480 & 39.0 & 34.9 & 13.8 & 56.5 & 0.62 & 83.9 & 0.42 \\
\hline C60-HD & Punched & 339 & 480 & 39.0 & 83.1 & 32.8 & 71.0 & 1.17 & 98.8 & 0.84 \\
\hline C60-LD & Punched & 339 & 480 & 39.0 & 90.7 & 35.8 & 71.0 & 1.28 & 98.8 & 0.92 \\
\hline W60-E-1.2 & Embossed & 388 & 481 & 33.8 & 25.0 & 9.5 & 95.7 & 0.26 & 119.5 & 0.21 \\
\hline W60-MD-1.2-n`1 & Punched & 388 & 481 & 33.8 & 179.1 & 68.3 & 146.6 & 1.22 & 181.1 & 0.99 \\
\hline W60-MD-1.2-n ${ }^{\circ} 2$ & Punched & 388 & 481 & 33.8 & 176.8 & 67.4 & 146.6 & 1.21 & 181.1 & 0.98 \\
\hline W60-MD-1.2-n³ & Punched & 388 & 481 & 33.8 & 175.7 & 67.0 & 146.6 & 1.20 & 181.1 & 0.97 \\
\hline W60-MD-n¹ & Punched & 377 & 474 & 31.4 & 155.0 & 78.8 & 119.8 & 1.29 & 150.7 & 1.03 \\
\hline W60-MD-n² & Punched & 377 & 474 & 31.4 & 152.5 & 77.5 & 119.8 & 1.27 & 150.7 & 1.01 \\
\hline W60-MD-n³ & Punched & 377 & 474 & 31.4 & 156.0 & 79.3 & 119.8 & 1.30 & 150.7 & 1.04 \\
\hline W60-MD-LC-n¹ & Punched & 388 & 481 & 24.3 & 146.4 & 74.4 & 123.3 & 1.19 & 152.0 & 0.96 \\
\hline W60-MD-LC-n² & Punched & 388 & 481 & 24.3 & 125.9 & 64.0 & 123.3 & 1.02 & 152.0 & 0.83 \\
\hline W60-MD-LC-n³ & Punched & 388 & 481 & 24.3 & 141.7 & 72.0 & 123.3 & 1.15 & 152.0 & 0.93 \\
\hline
\end{tabular}




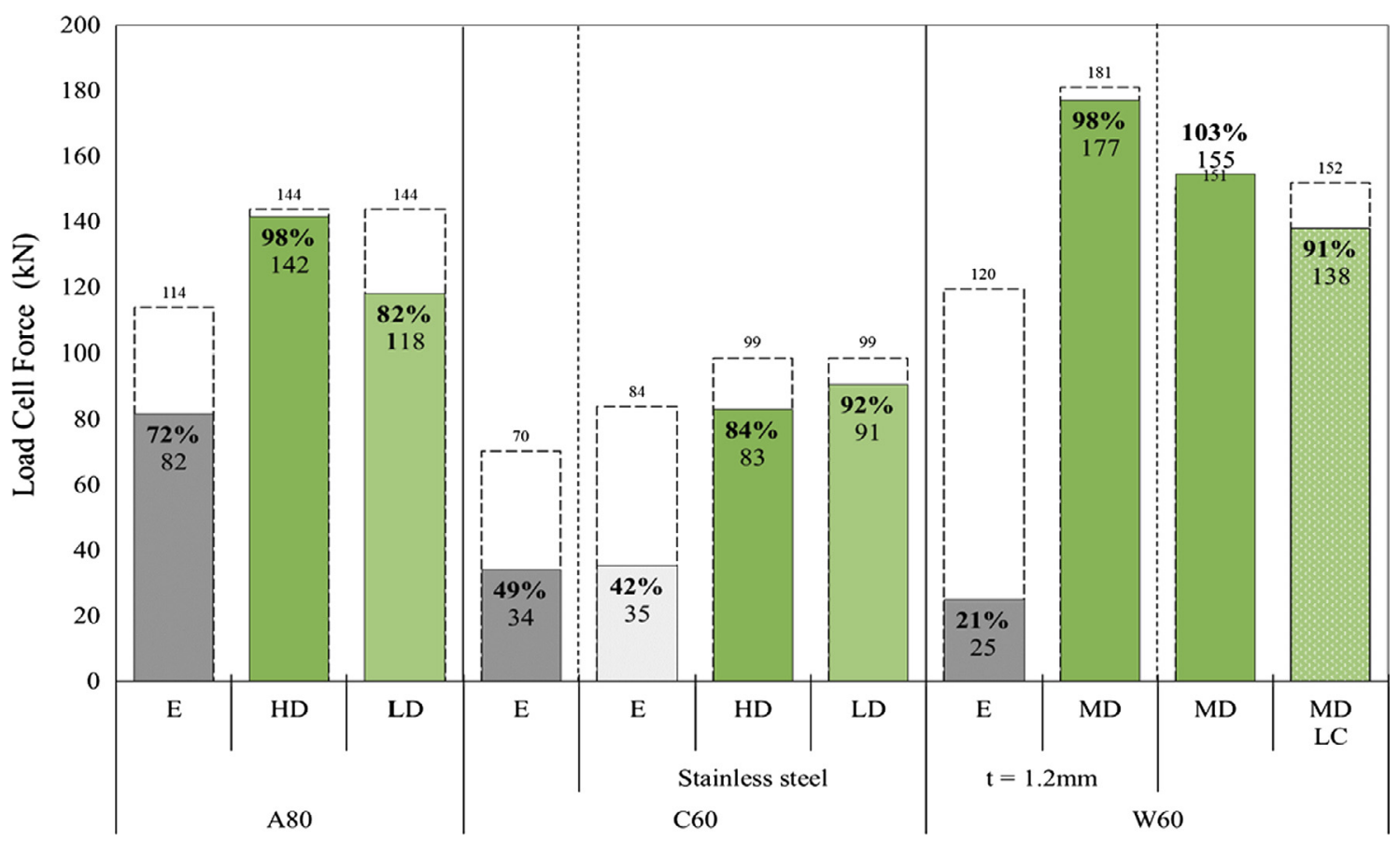

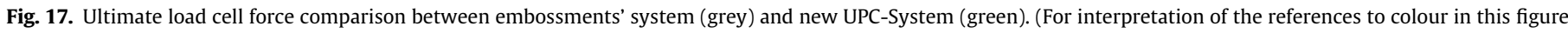
legend, the reader is referred to the web version of this article.)

greater (see Table 2). The load-deflection curves (Fig. 18) show a clear ductile-type response, especially the A80-HD curve due to steel yielding. However, the final collapse point was brittle due to sudden longitudinal slip Fig. 19.

It must be noted that the LD specimen failure load is lower than the HD case. It can be concluded from this fact that the longitudinal shear strength of the UPC-System depends on the punching den- sity. Further research will be carried out into this issue in the near future.

Strain gauge measurements of punched specimens, up to 1500 $\mu \varepsilon$, showed that the steel was widely yielded before failure, see Fig. 18. This is in accordance with the fact that the experimental failure bending load is similar to the theoretical value calculated considering full composite behaviour, as shown in Table 3. Finally, the measurements shown in Fig. 18 have also verified the linearity

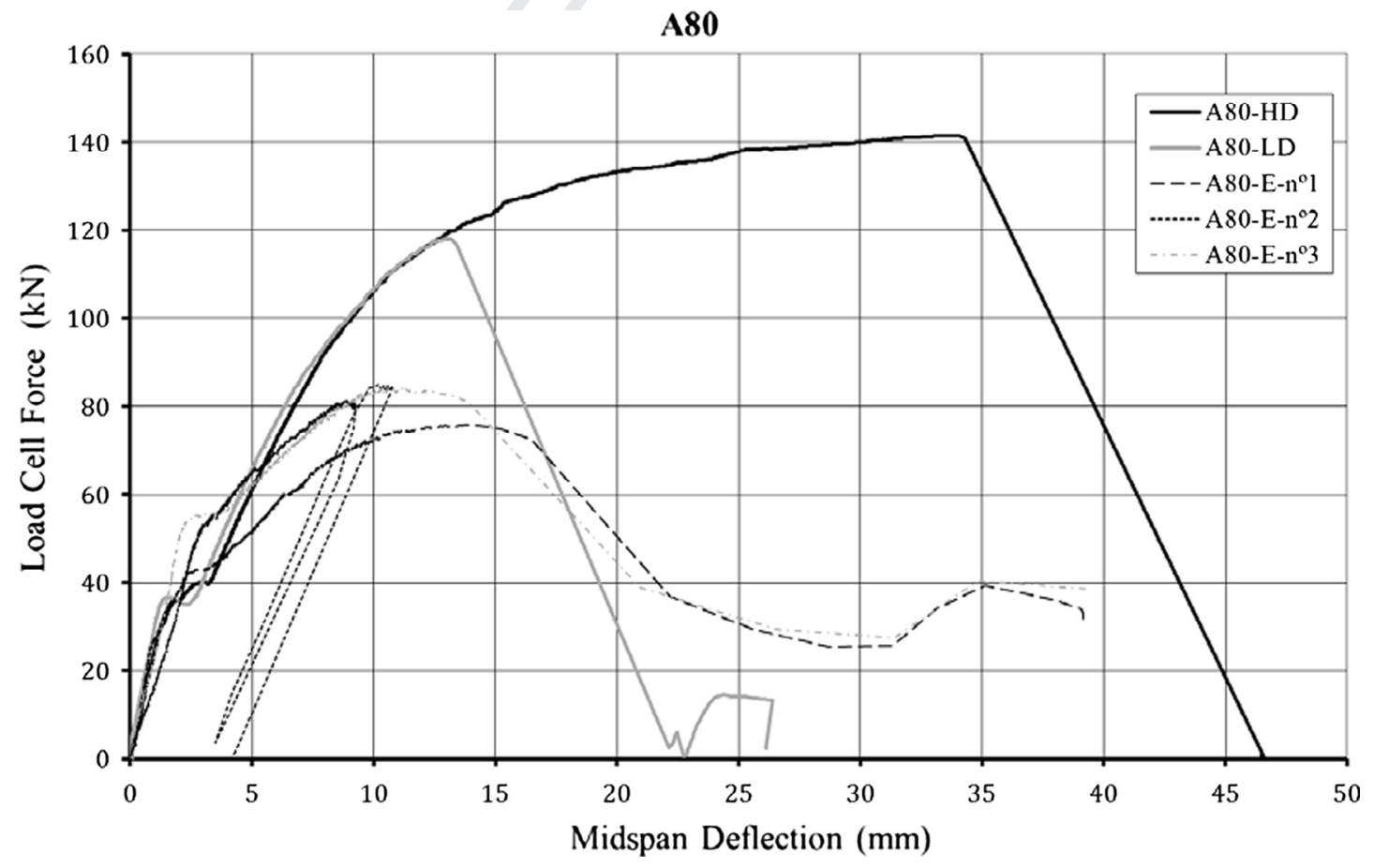

Fig. 18. F-d curves of A80 slabs: punched (-LD-HD) and embossed (-E- $\left.n^{\circ} 1,2,3\right)$ sheeting. 


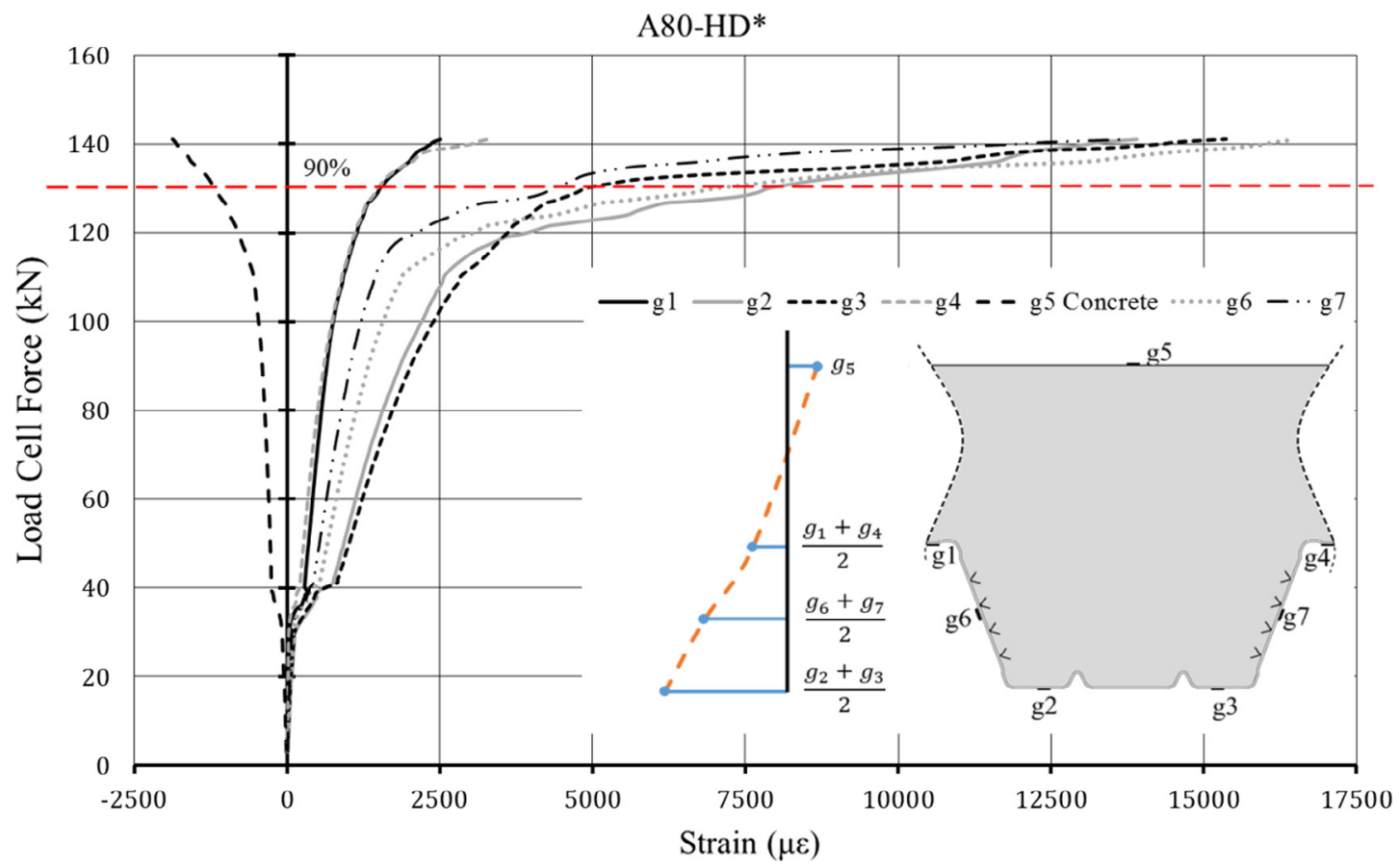

Fig. 19. Force-Strain curves of A80-HD specimen. Strain distribution at $90 \%$ of the maximum load cell force.

of strains throughout the depth of the slab, confirming the occurrence of full-connection behaviour.

\subsection{C60 specimens}

The slabs made with the conventional embossed C60 sheeting, galvanized and stainless, also showed the common partial connection slipping behaviour until the ultimate force was reached. In the case of stainless steel profile C60 specimens with embossments, the first slip occurred much earlier, even during the preliminary cycling loading prescribed in Eurocode-4 [6], as shown in Fig. 21 for slabs no's 2 and 3. In fact, first slip appeared in the very first loading cycle.

In the case of punched specimens, the ultimate stresses were reached in both materials without any slip, until failure of the slab. Consequently, the ultimate bending moment corresponds to the theoretical full-connection bending moment of the composite cross-section (see the force ratios in Table 3). The steel yielded at both flanges and the concrete crushed at upper fibres in several cross sections within the central span (Fig. 20b), as corroborated by strain gauge measurements (Fig. 24 and Fig. 25).
The punched specimens were significantly curved as shown in Fig. 20a, up to the point of saturating the displacement sensors, even the one measuring the curvature (d5), showing an extremely high ductile behaviour, as shown in Fig. 20. The slabs' curvature remained after the load system was released and the tested slabs were stored, with permanent deflections $>50 \mathrm{~mm}$.

Fig. 21 shows the extraordinary difference between the partial connection behaviour of common slabs with embossments and the full-connection of the new UPC-System. The maximum deflection was over $200 \mathrm{~mm}$, and was only limited by the extension capability of the hydraulic cylinder, which was the main reason for finishing the tests of both slabs with the UPC-System, together with the fact that the maximum load had been reached and the decreasing branch had been widely developed, within the vertical line in Fig. 20a due to the saturation of the displacement sensors. Although the displacement sensors reached their limit, the load cell captured the load force until the end of the test. Therefore, the load bearing capacity was properly measured and the beginning of the collapse branch was detected when the load started decreasing. The whole force-deflection curve has shown to be extremely ductile.

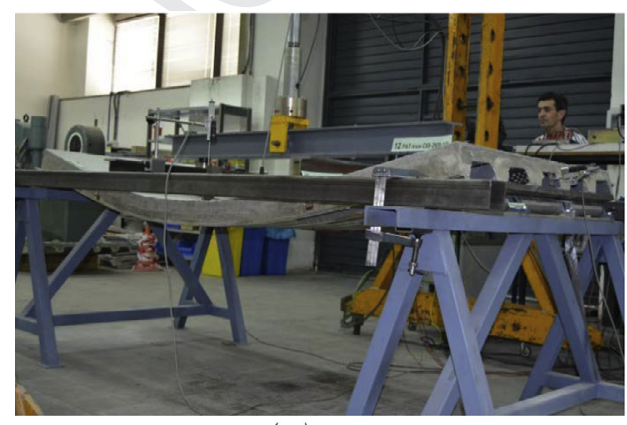

(a)

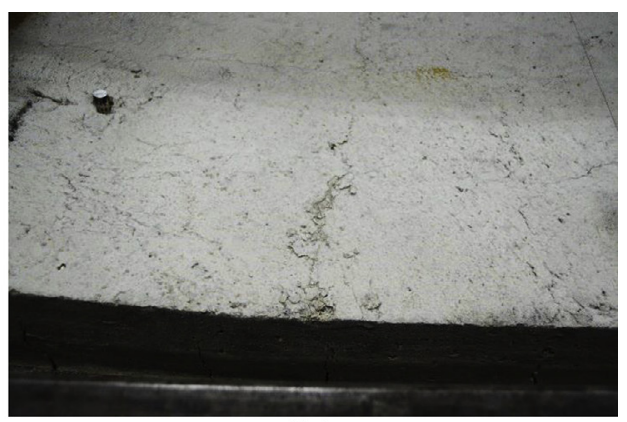

(b)

Fig. 20. C60-LD test: a) Extreme bending without slipping; b) Concrete crushing on the upper surface of the slab. 
C60

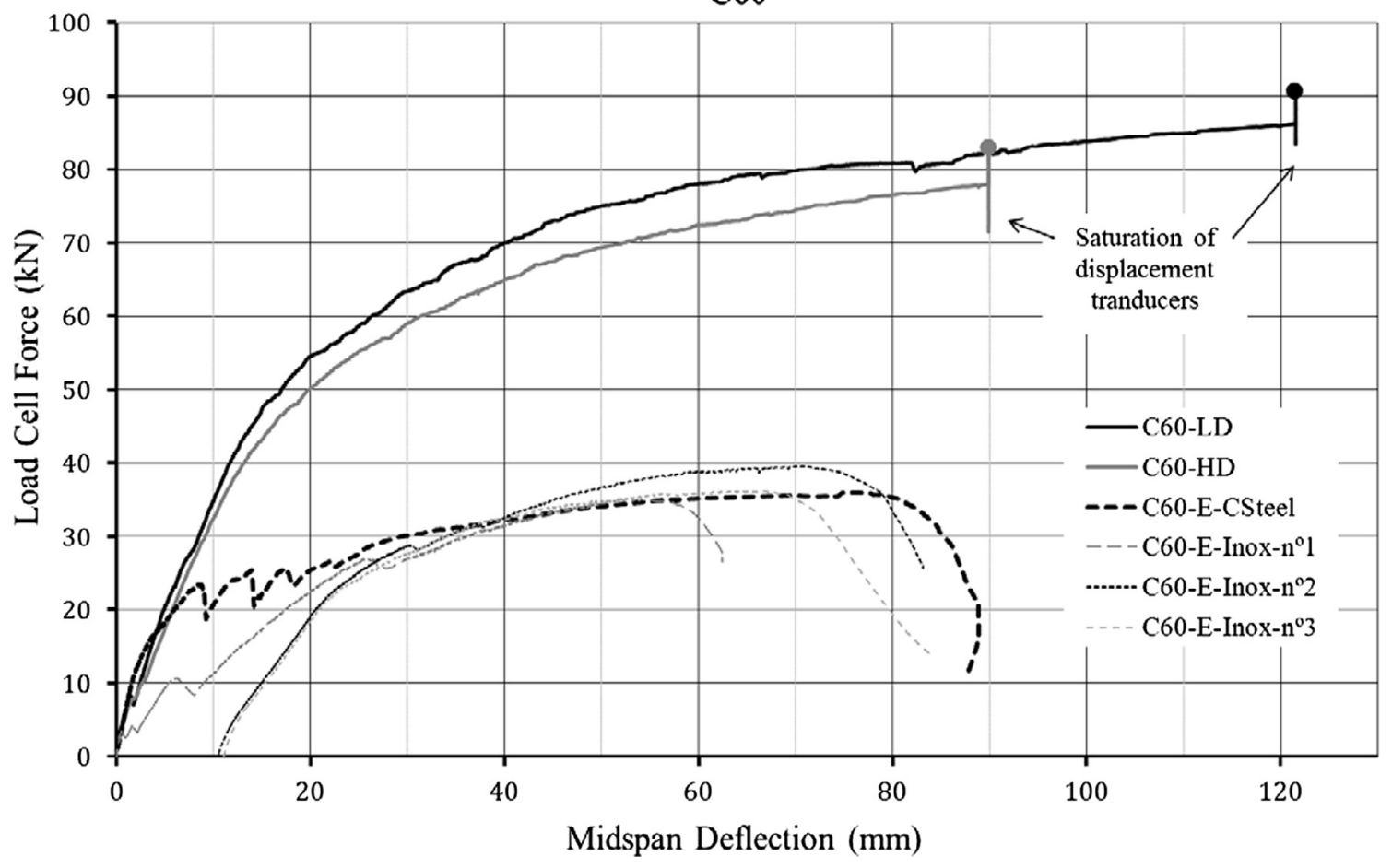

Fig. 21. F-d curves of C60 slabs: embossed stainless or carbon steel (-E-) and punched stainless steel (-HD-LD) sheeting.

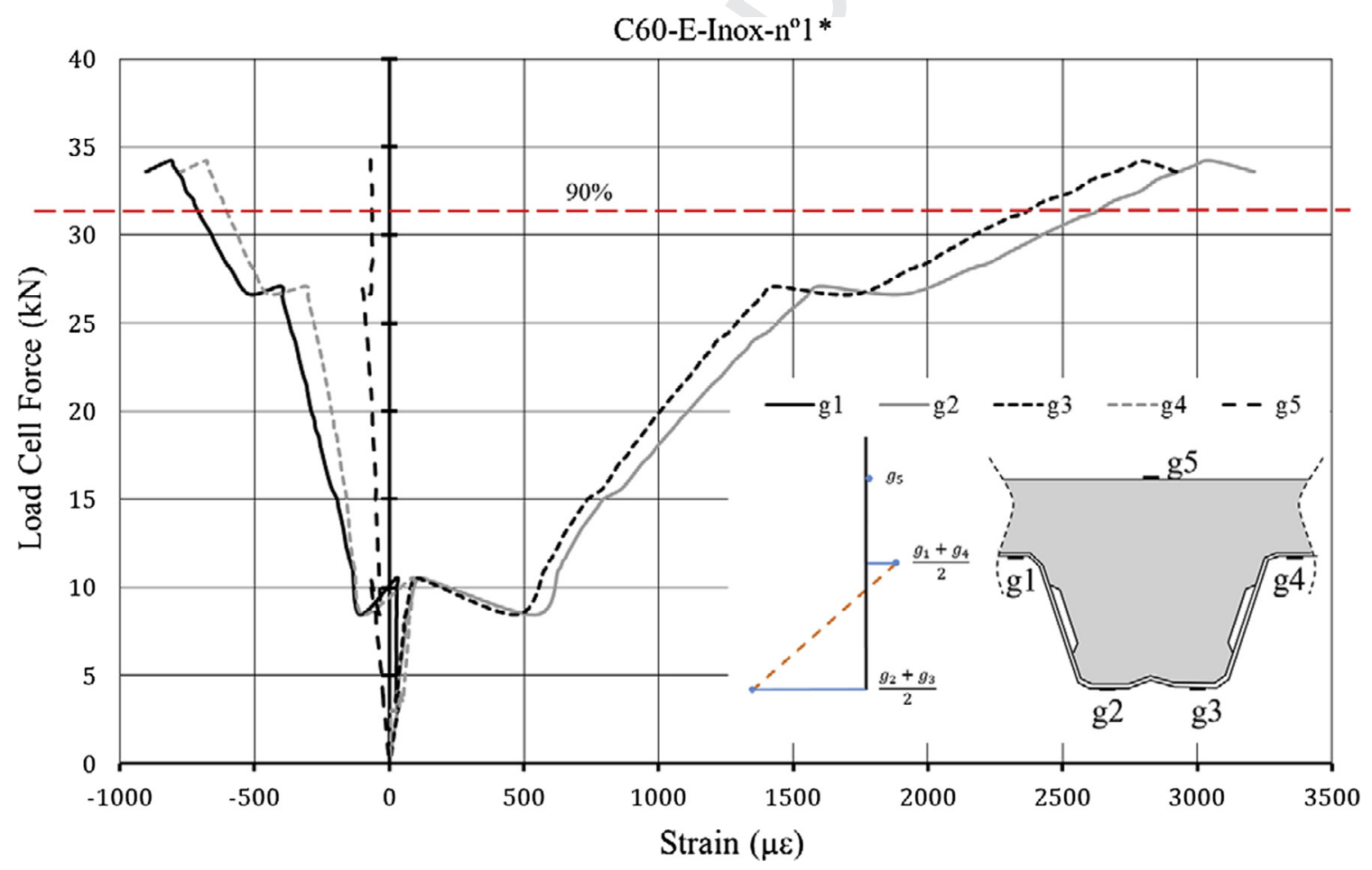

Fig. 22. Force-Strains of specimen C60-E-Inox-n ${ }^{\circ} 1$ and strain distribution at $90 \%$ of the maximum load cell force.

On the other hand, in contrast to the A80 case, the LD specimens have shown higher strength than the HD. However, these differences in strength cannot be related to punching density, because the failure of both specimens was due to yielding of materials through bending stresses, not to longitudinal shear. The new punching system, neither LD nor HD, did not fail.

In Figs. 21 and 22, the strain gauges measurements show the strain discontinuity due to slip corresponding to the partial con- nection behaviour of the embossed specimens, giving compressive values in the upper fibres of the steel sheeting (Figs. 22 and 23). In contrast, the punched specimens show a quasi-linear distribution of strains (Figs. 24 and 25).

Fig. 26 shows that cracking of concrete occurred along the entire slab regardless of the position of the crack inducer. Typical pure bending vertical cracks were observed within the central span 


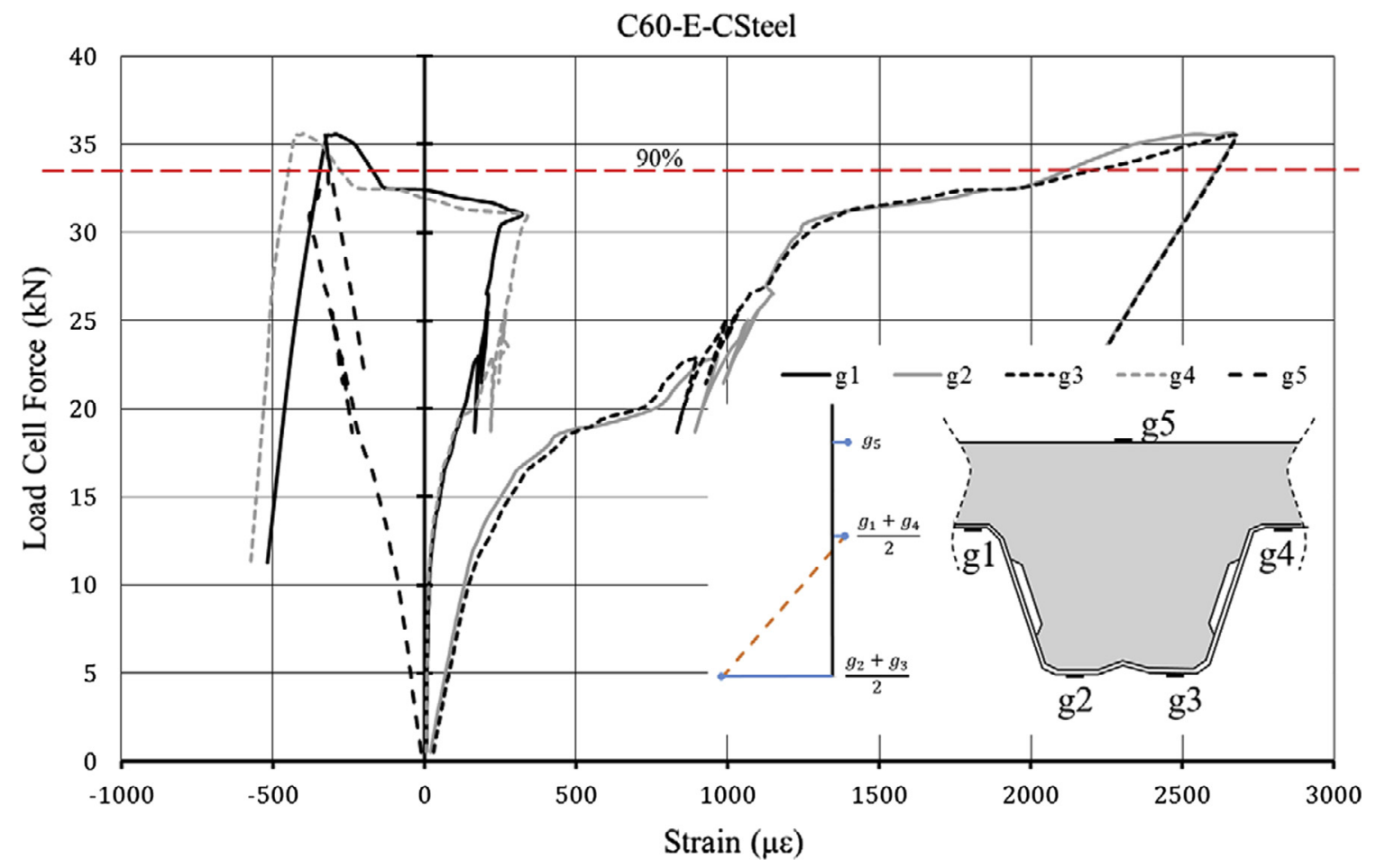

Fig. 23. Force-Strains of C60-E-CSteel specimen and strain distribution at $90 \%$ of the maximum load cell force.

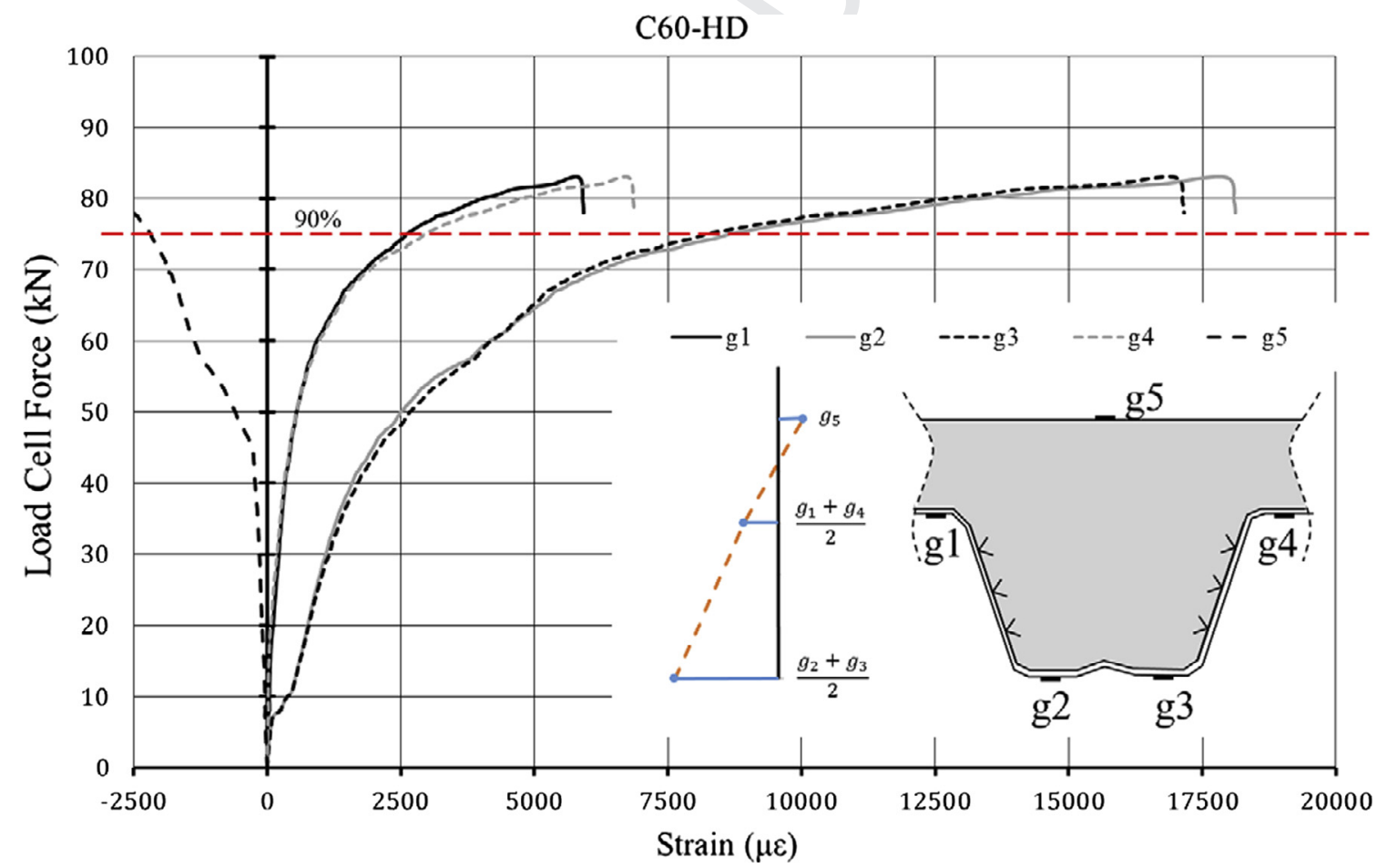

Fig. 24. Force-Strain of C60-HD and strain distribution at $90 \%$ of the maximum load cell force.

(Fig. 26a), and tilted cracks were also clearly developed at shear span (Fig. 26b).

\subsection{W60 specimens}

The common embossed specimen developed early slip between steel profile and concrete, showing the partial connection strains scheme and a much lower ultimate load, less than $25 \mathrm{kN}$, compared to $175 \mathrm{kN}$ of the punched specimen (see Table 2), as predicted in Section 0.

Likewise, strain gauges measurements have shown the strain discontinuity due to slip corresponding to partial connection behaviour, including compressive values in the upper fibres of the steel sheeting (Fig. 27). 


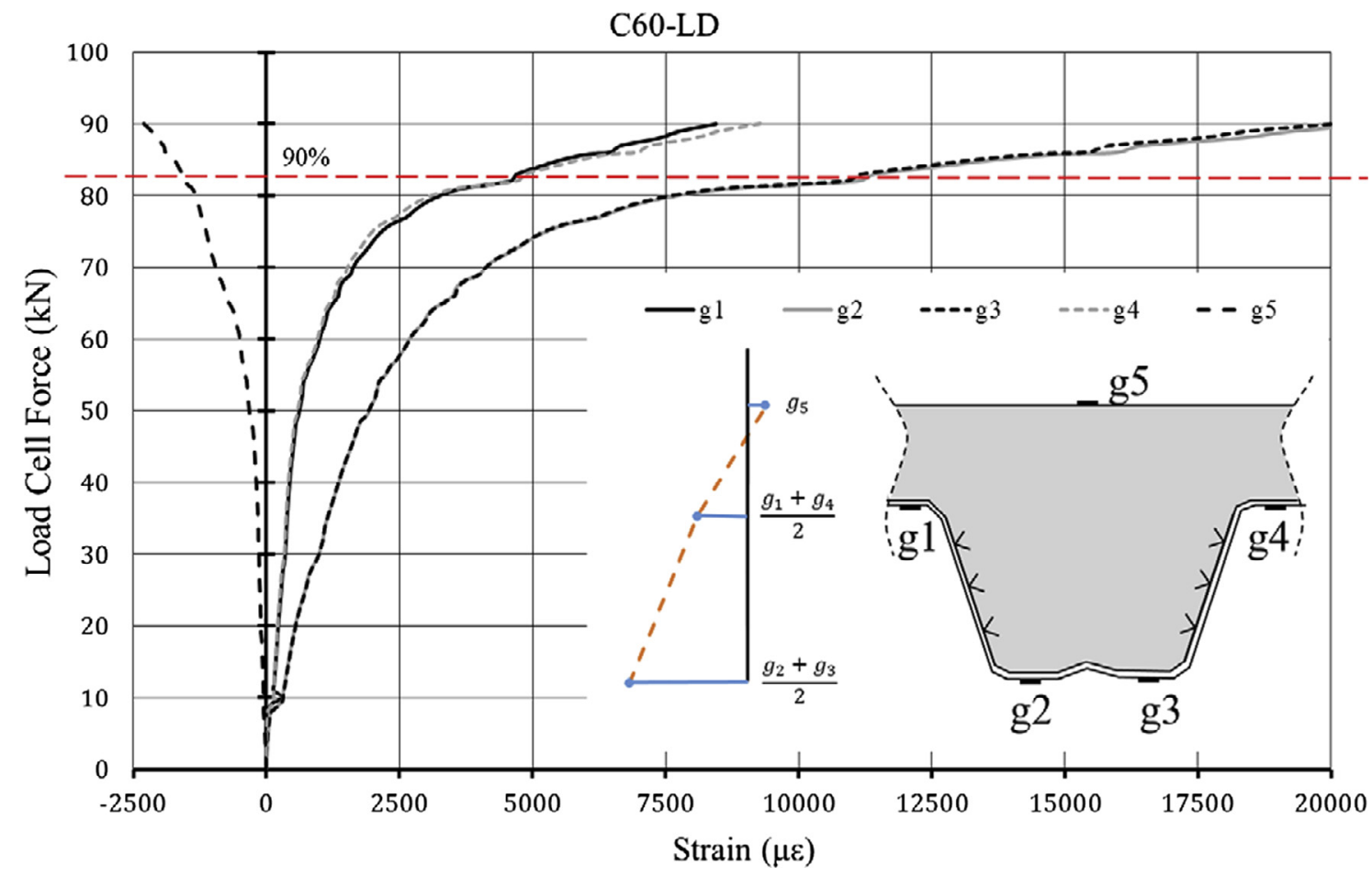

Fig. 25. Force-Strain of C60-LD and strain distribution at $90 \%$ of the maximum load cell force.

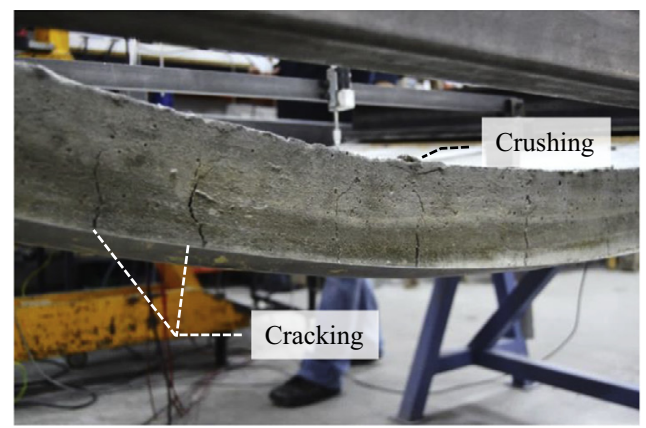

(a)

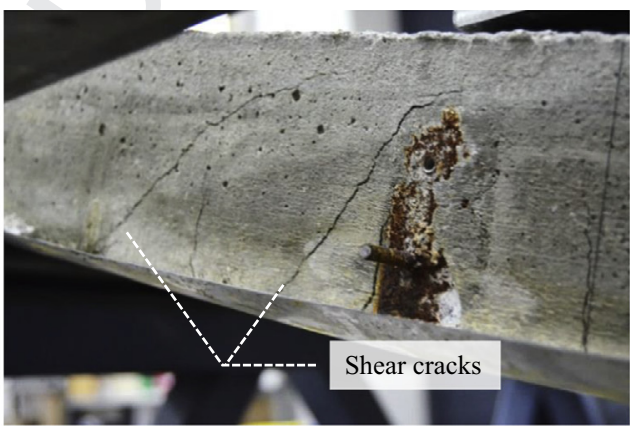

(b)

Fig. 26. C60-LD specimen: a) Pure bending cracks and crush at central span b) Cracks at left side shear span.

On the other hand, all the punched specimens developed widely yielded strains (Fig. 28) showing the strain linear full-connection scheme throughout the depth of the slab, until failure without any slip. The failure bending moment corresponds to the theoretical ultimate plastic bending moment of the composite crosssection (Table 3), although, the final collapse of the $1.2 \mathrm{~mm}$ steel thickness slabs was due to longitudinal slip.

The $0.75 \mathrm{~mm}$ steel thickness specimens failed completely due to bending, until the breakage of the steel in tension and the concrete in compression at the centre of the span, without any slip, as shown in Fig. 29c.

Fig. 29a and b show the concrete and the steel crown-shaped cuttings after slipping. Notice that the concrete surface (a) is clearly eroded while steel crowns (b) remain undeformed.

\section{Conclusions}

This research shows the significant improvement that the new UPC bonding technology contributes to steel-concrete composite slabs. This invention achieves full connection until material yielding and, in practice, the suppression of the longitudinal shear failure mode.

The main technical findings regarding the new UPC-System can be summarized as follow:

1) All specimens with the UPC-System have clearly achieved full connection between steel sheeting and concrete until the yielding of both materials, and until the final failure of the slab without any relative slip, regardless of the sheeting profile design and the material type: carbon galvanized steel, ferritic stainless steel, normal concrete or lightweight aggregate concrete.

2) The ultimate loads of all slabs with the UPC-System are significantly greater than the ultimate loads of the same slabs using conventional embossments.

3) The bending failure mode is the one that develops first. The theoretical ultimate plastic bending moment of the composite cross-section has been reached in all punched specimens. 
W60-E-1.2

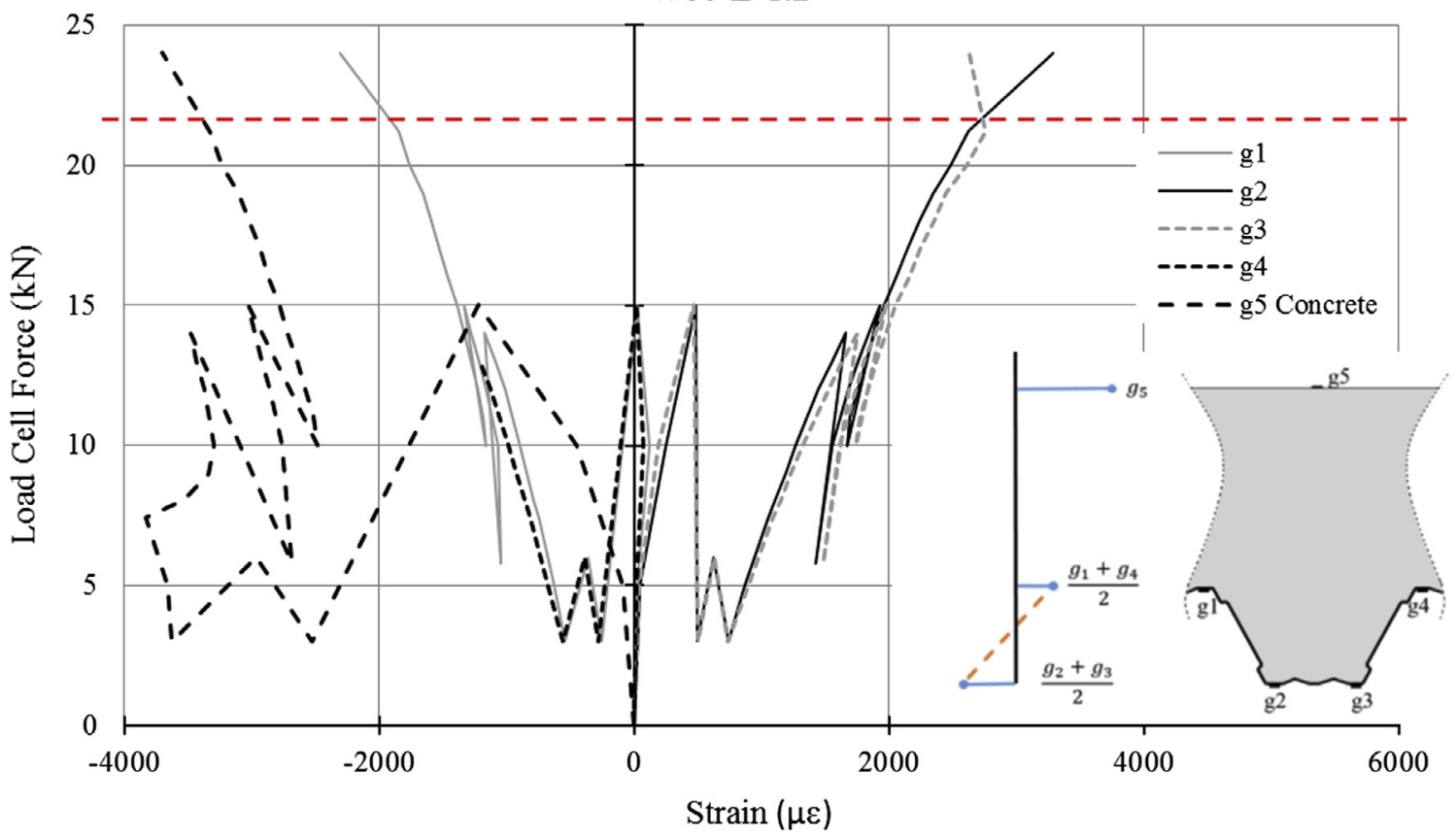

Fig. 27. W60-E-1.2 specimen: Force-strain curves and strain distribution at 90\% of the maximum load cell force.

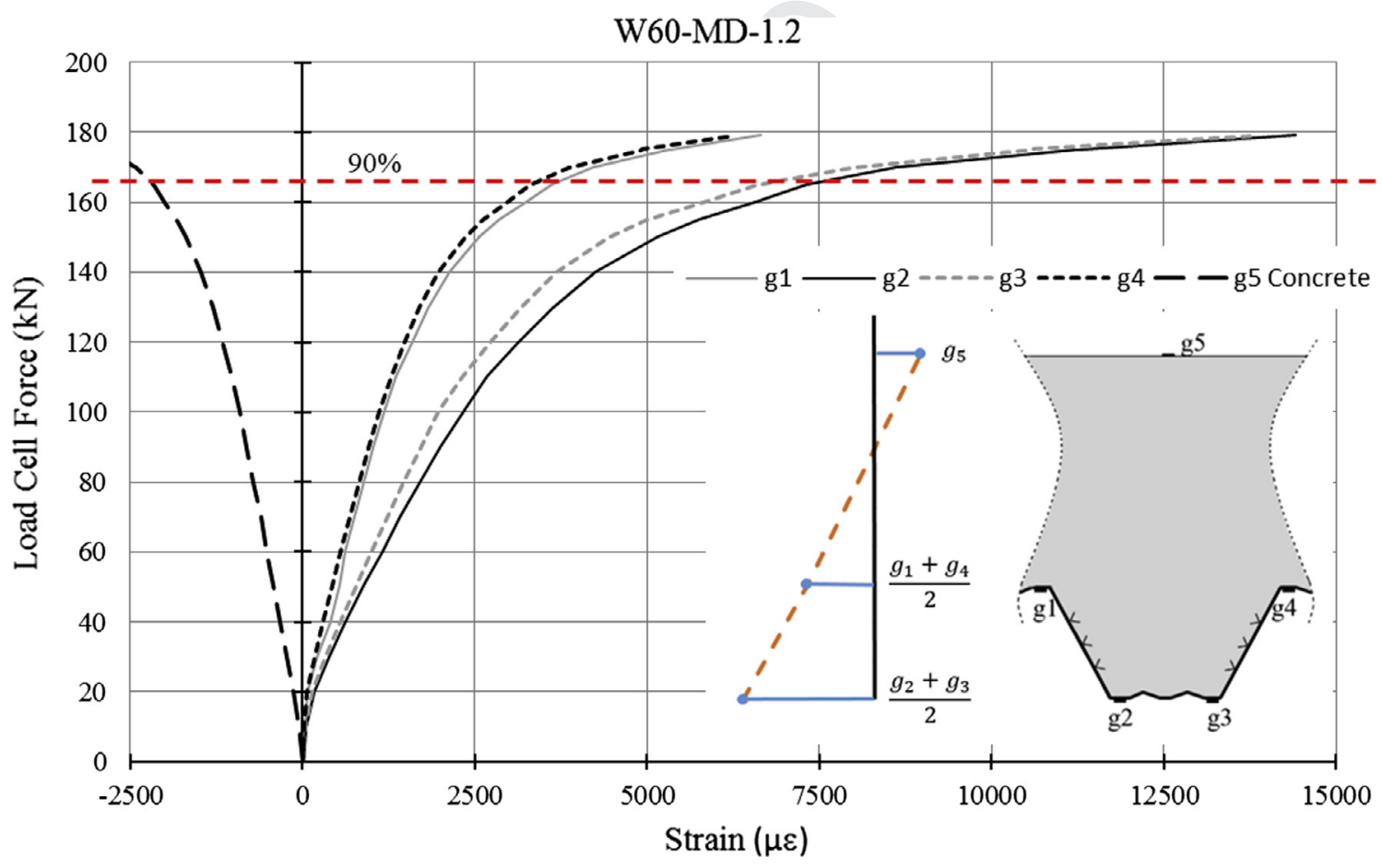

Fig. 28. Force-Strain of W60-MD-1.2- ${ }^{\circ} 1$ and strain distribution at $90 \%$ of the maximum load cell force.

4) The final collapse of A80 and W60-1.2 mm punched specimens occurred due to longitudinal slip, after yielding of the whole cross-section. Both bending and longitudinal slip failure modes could be considered to be present simultaneously.

5) The force-strain curves of punched specimens have shown a ductile-type behaviour because failure is due to yielding of materials.
6) The strain measurements in all slabs have demonstrated the linearity and continuity of strains in punched specimens, as corresponds to full connection. In contrast, the embossed specimens have shown strain discontinuity due to slip corresponding to partial connection behaviour, giving compressive values in the upper fibres of the steel sheeting.

7) Further research is necessary to evaluate the real strength dependence on punching density. 


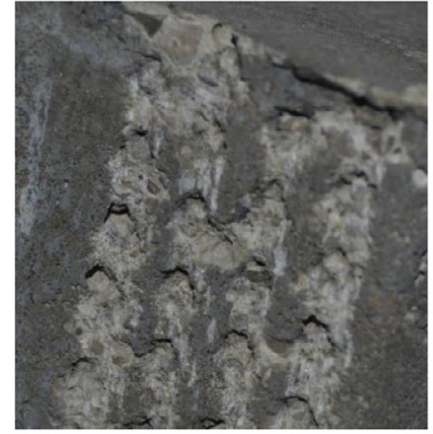

(a)

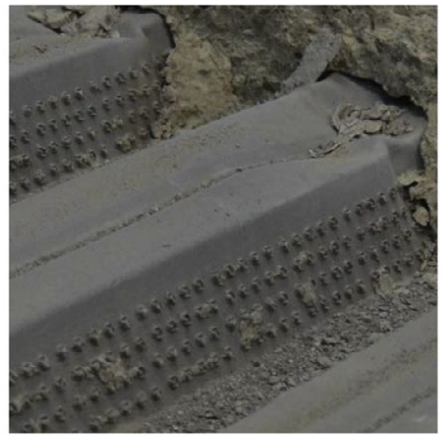

(b)

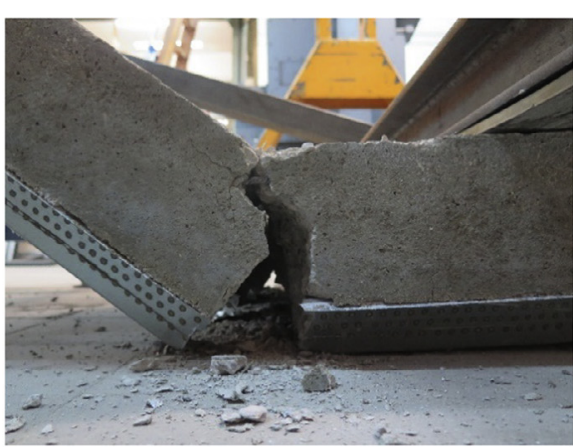

(c)

Fig. 29. Concrete (a) and steel (b) surfaces after test in case W60-MD-1.2 (c) Bending failure of W60-MD specimens.

\section{Funding}

Acquisition of materials and tools for developing the punched prototypes was funded by a specific research grant from the Universitat Politècnica de Catalunya.

\section{Acknowledgments}

The authors want to thank the PhD candidate R. Gámez and the lab technician F-J. Garcia for their kind collaboration.

\section{References}

[1] R.Q. Bridge, M. Patrick, Innovation in Composite Slabs Incorporating Profiled Steel Sheeting, Advances in Building Technology, Elsevier Science Ltd., 2002.

[2] M.L. Porter, C.E. Ekberg, Investigation of Cold-formed Steel-deck-reinforced Concrete Floor Slabs, in: Proceeding of the 1th International Specialty Conference on Cold-Formed Steel Structures. University of Missouri-Rolla, 1971. http://scholarsmine.mst.edu/isccss/1iccfss/1iccfss-session6/2.

[3] R.P. Johnson, D. Anderson, Designers' guide to EN-1994-1-1 Eurocode 4: design of composite steel and concrete structures. Part 1.1: General rules and rules for buildings, Thomas Telford. London, 2004.

[4] M. Leskelä, et al., Shear Connections in Composite Flexural Members of Steel and Concrete, 1st Edition. European Convention for Constructional Steelwork. ECCS Publication no138, Brussels, 2017.

[5] American Society of Civil Engineers (ASCE) Standard for the Structural Design of Composite Slabs, ANSI/ASCE 3-91, New York, 1992.

[6] CEN (European Committee for Standardization) Eurocode 4: Design of composite steel and concrete structures - Part 1-1: General rules and rules for buildings EN 1994-1-1:2004 and AC: 2009, Brussels, 2004 and 2009.

[7] Avis Techniques Cahier des prescriptions techniques communes aux procédés des planchers collaborants, Centre Scientifique et Technique du Bâtiment. Cahiers du CSTB, Marné la Vallée, France, 2014.

[8] R. Abdullah, W. Easterling, New modelling and evaluation procedures for horizontal shear bond in composite slabs, J. Constr. Steel Res. 65 (2009) 891899, https://doi.org/10.1016/j.jcsr.2008.10.009.

[9] R. Abdullah, A.B. Hong Kueh, I.S. Ibrahim, W. Easterling, Characterization of shear bond stress for design of composite slabs using an improved partial shear connection method, J. Civ. Eng. Manage., 21:6, 720-732. https://doi.org/ 10.3846/13923730.2014.893919.

[10] M. Ferrer, F. Marimon, I. Arrayago, E. Real, E. Mirambell, Structural and thermal performance of steel-concrete composite floor systems: Composite slabs test, http://www.steel-stainless.org/media/1196/safss-03-03.pdf. Task 3.3 of the European Research project Structural Application of Ferritic Stainless Steels (SAFSS) funded by European Community's Research Fund for Coal and Steel (RFCS)
11] K.M.A. Hossain et al., High performance composite slabs with profiled stee deck and engineered cementitious composite - strength and shear bond characteristics, Constr. Build. Mater. 125 (2016) 227-240, https://doi.org/ 10.1016/j.conbuildmat.2016.08.021.

12] D. Waldmann, A. May, V.B. Thapa, Influence of the sheet profile design on the composite action of slabs made of lightweight woodchip concrete, Constr.

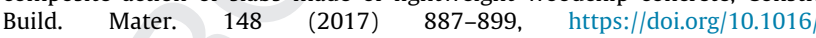
j.conbuildmat.2017.04.193.

[13] M.L. Porter, C.E. Ekberg, Coating Effects of Cold-Formed Steel Deck Slabs, in: Proceeding of the 5th International Specialty Conference on Cold-Formed Steel Structures. University of Missouri-Rolla, 1980. http://scholarsmine.mst.edu isccss/5iccfss/5iccfss-session7/1.

[14] M. Crisinel, M. Ferrer, F. Marimon, M. Rossich, Influence of sheet surface conditions and concrete strength on the longitudinal shear resistance of composite slabs, A Forecast of the Future of Steel and Composite SteelConcrete Structures- Prof. Jean-Marie Aribert Retirement Symposium, pag. 233-244, Rennes-France, 2006. https://infoscience.epfl.ch/record/116041? ln= en.

[15] M. Ferrer, F. Marimon, M. Crisinel, Designing cold-formed steel sheets for composite slabs: an experimentally validated FEM approach to slip failure mechanics, Thin-walled Struct. 44 (2006) 1261-1271, https://doi.org/10.1016/ j.tws.2007.01.010.

[16] J. Holomek, M. Bajera, M. Vilda, Test arrangement of small-scale shear tests of composite slabs, Procedia Eng. 161 (2016) 716-721, https://doi.org/10.1016/j. proeng.2016.08.749.

[17] H. Cifuentes, F. Medina, Experimental study on shear bond behaviour of composite slabs according to eurocode 4, J. Constr. Steel Res. 82 (2013) 99110, https://doi.org/10.1016/j.jcsr.2012.12.009.

[18] A. Gholamhoseini, R.I. Gilbert, M.A. Bradford, Z.T. Chang, Longitudinal shear stress and bond-slip relationships in composite concrete slabs, J. Struct. Eng. 69 (2014) 37-48, https://doi.org/10.1016/j.engstruct.2014.03.008.

[19] M. Veljkovic, Behaviour and resistance of composite slabs, PhD dissertation, Lulea University of Technology, Lulea, Sweden, 1996. https://www.diva-portal. org/smash/get/diva2:991211/FULLTEXT01.pdf.

[20] J. Ríos, H. Cifuentes, A. Martínez, F. Medina, Numerical modelling of the shearbond behaviour of composite slabs in four and six-point bending tests, Eng. Struct. 133 (2017) 91-104, https://doi.org/10.1016/j.engstruct.2016.12.025.

[21] V. Marimuthu V. et al., Experimental studies on composite deck slabs to determine the shear-bond characteristic $(\mathrm{m}-\mathrm{k})$ values of the embossed profiled sheet, J. Constr. Steel Res. 63 (2007) 791-803, https://doi.org/ 10.1016/j.jcsr.2006.07.009.

[22] S. Chen, S. Xiaoyu, Shear bond mechanism of composite slabs - a universal FE approach, J. Constr. Steel Res. 67 (2011) 1475-1484, https://doi.org/10.1016/j. jcsr.2011.03.021.

[23] M. Ferrer, F. Marimon, Sistema para la conexión entre chapa de acero y hormigón / System for connecting together steel sheet and concrete., Patent ES2344389, EP2305911, WO2010037876. Applicant: Universitat Politècnica de Catalunya. 